\author{
RESEARCH ARTICLE \\ 10.1029/2020JC016463 \\ Key Points: \\ - Performance of the Mercator $1 / 12^{\circ}$ \\ system is assessed using 12 years \\ (2007-2018) of independent \\ observations in the Western Nansen \\ Basin \\ - Winters 2012/13 and 2017/18 stood \\ out with the deepest mixed layers \\ and exceptional sea-ice retreat on \\ the slope and Yermak Plateau \\ - Winter deep convection and \\ recurrent troughs outflows \\ northeast of Svalbard dramatically \\ modified Atlantic Water
}

Supporting Information:

- Supporting Information S1

- Movie S1

- Movie S2

Correspondence to:

M. Athanase,

mathanase@locean-ipsl.upmc.fr

Citation:

Athanase, M., Provost, C.,

Pérez-Hernández, M. D.,

Sennéchael, N., Bertosio, C., Artana, C. et al. (2020). Atlantic water modification north of Svalbard in the Mercator physical system from 2007 to 2020. Journal of Geophysical Research: Oceans, 125, e2020JC016463. https:// doi.org/10.1029/2020JC016463

Received 30 MAY 2020

Accepted 12 SEP 2020

Accepted article online 17 SEP 2020

(c)2020. American Geophysical Union. All Rights Reserved.

\section{Atlantic Water Modification North of Svalbard in the Mercator Physical System From 2007 to 2020}

\author{
Marylou Athanase ${ }^{1}$ iD, Christine Provost ${ }^{1}$ iD, M. Dolores Pérez-Hernández ${ }^{2}$ iD, \\ Nathalie Sennéchael $^{1}$ (D), Cécilia Bertosio ${ }^{1}$ (D), Camila Artana ${ }^{3}$ iD, Gilles Garric ${ }^{3}$ (D), \\ and Jean-Michel Lellouche ${ }^{3}$ iD \\ ${ }^{1}$ Laboratoire LOCEAN-IPSL, Sorbonne Université (UPMC, University Paris 6), CNRS, IRD, MNHN, Paris, France, \\ ${ }^{2}$ Unidad de Océano y Clima, Instituto de Oceanografía y Cambio Global, IOCAG, Universidad de Las Palmas de Gran \\ Canaria, UPGC, Unidad Asociada ULPGC-CSIC, Spain, ${ }^{3}$ MERCATOR-OCEAN, Parc Technologique du Canal, 8-10 rue \\ Hermès, Ramonville Saint Agne, France
}

Abstract The Atlantic Water (AW) inflow through Fram Strait, largest oceanic heat source to the Arctic Ocean, undergoes substantial modifications in the Western Nansen Basin (WNB). Evaluation of the Mercator system in the WNB, using 1,500 independent temperature-salinity profiles and five years of mooring data, highlighted its performance in representing realistic AW inflow and hydrographic properties. In particular, favorable comparisons with mooring time-series documenting deep winter mixed layers and changes in AW properties led us to examine winter conditions in the WNB over the 2007-2020 period. The model helped describe the interannual variations of winter mixed layers and documented several processes at stake in modifying AW beyond winter convection: trough outflows and lateral exchange through vigorous eddies. Recently modified AW, either via local convection or trough outflows, were identified as homogeneous layers of low buoyancy frequency. Over the 2007-2020 period, two winters stood out with extreme deep mixed layers in areas that used to be ice-covered: 2017/18 over the northern Yermak Plateau-Sofia Deep; 2012/13 on the continental slope northeast of Svalbard with the coldest and freshest modified AW of the 12-year time series. The northern Yermak Plateau-Sofia Deep and continental slope areas became "Marginal Convection Zones" in 2011 with, from then on, occasionally ice-free conditions, 50-m-ocean temperatures always above $0{ }^{\circ} \mathrm{C}$ and highly variable mixed layer depths and ocean-to-atmosphere heat fluxes. In the WNB where observations require considerable efforts and resources, the Mercator system proved to be a good tool to assess Atlantic Water modifications in winter.

Plain Language Summary The Atlantic Water inflow through Fram Strait, largest oceanic heat source to the Arctic Ocean, undergoes severe modifications in the Western Nansen Basin in winter. We used 14 years of high-resolution ocean model simulations to identify winters with intense Atlantic Water modifications (cooling and freshening) in this region. Over the 2007-2020 period, two winters stood out with extreme deep convection events in areas that used to be ice-covered: 2017/18 over the northern Yermak Plateau; and 2012/13 on the continental slope northeast of Svalbard, with the coldest, freshest modified Atlantic Water over 2007-2020. The northern Yermak Plateau and continental slope became "Marginal Convection Zones" in 2011 as they started to occasionally exhibit open-ocean conditions in winter. In this region where observations require considerable efforts and resources, the model simulations proved to be a good tool to assess Atlantic Water modifications in winter. As the transition towards a seasonally ice-free Arctic Ocean continues, more years of extreme Atlantic Water modification can be expected.

\section{Introduction}

The Atlantic Water (AW) inflow through Fram Strait is the largest oceanic heat source to the Arctic Ocean (Aagaard et al., 1987). The West Spitsbergen Current carries the AW northward in Fram Strait and splits into several branches north of $79^{\circ} \mathrm{N}$ (Figure 1). A fraction of the water carried by the current does not enter the Arctic Ocean and recirculates back into Fram Strait through several recirculation pathways (e.g. Schauer et al., 2004; von Appen et al., 2016, Wekerle et al., 2017). The entrance of AW into the Nansen Basin divides into branches around and above the topographic obstacle of the Yermak Plateau: the Svalbard Branch crosses the Plateau following the $500 \mathrm{~m}$ isobath; the Yermak Pass Branch crosses further north around 


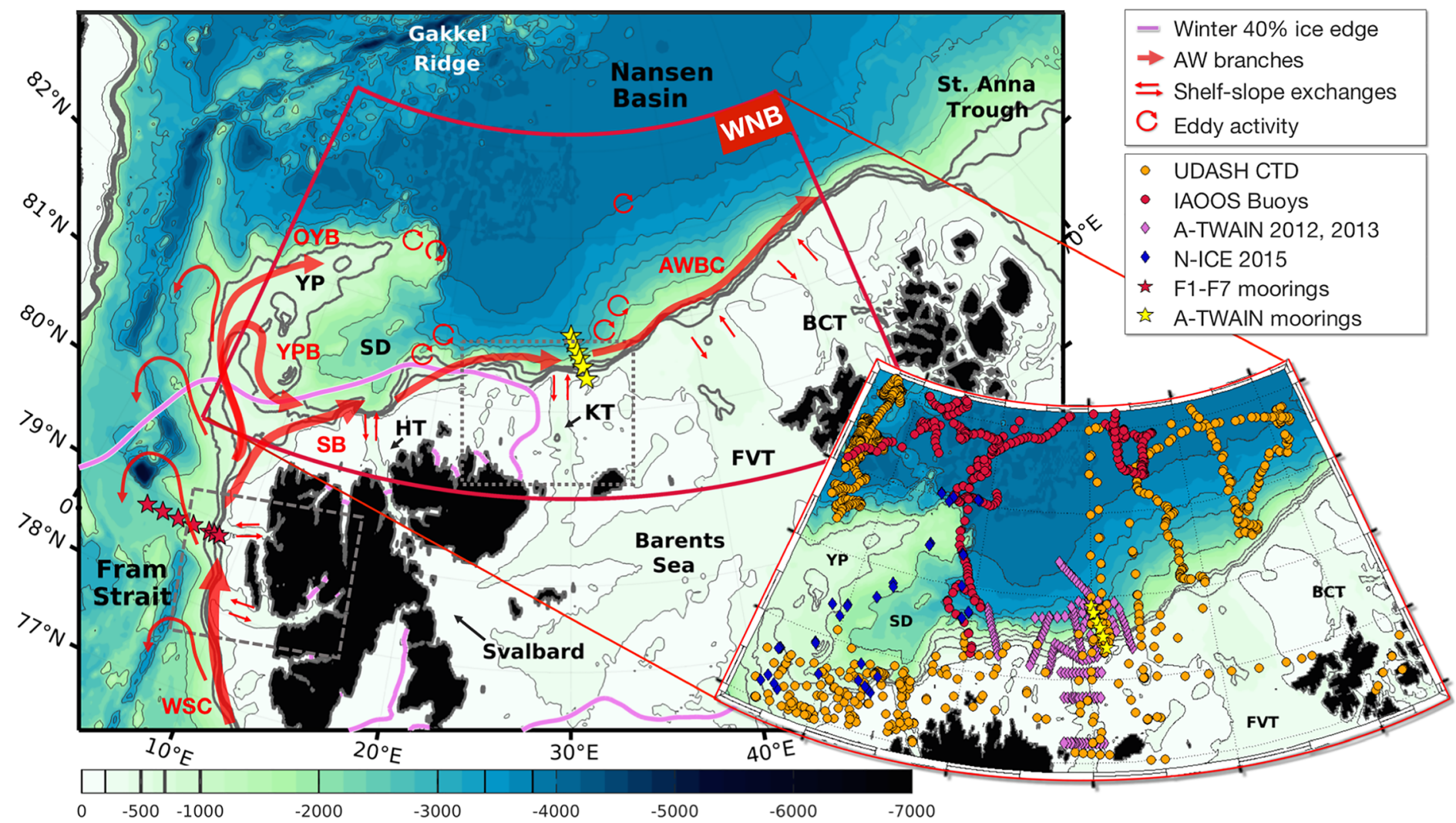

Figure 1. Major AW routes (red arrows) in the Western Nansen Basin (WNB; red box). WSC: West Spitsbergen current; SB: Svalbard branch; YPB: Yermak pass branch; OYB: Outer Yermak branch; AWBC: Atlantic water boundary current. Thin red lines in the Fram Strait represent recirculation branches. Winter ice edge (violet contour) corresponds to the 40\% isoline of the mean ice cover during winter months from October to march, over the 2007-2018 period. This winter ice-free area is the whalers' bay. The boxes in dashed and dotted gray lines delineate areas presented in Figure 5 (a-b) and (c-d) respectively. Markers indicate datasets used to evaluate the performance of the PSY4 system in the WNB. None of these in-situ data was assimilated. Red markers correspond to data used for detailed PSY4 model-observations comparisons in previous studies (IAOOS buoys in Koenig, Provost, Villacieros-Robineau, et al., 2017 and Athanase et al., 2019; Fram Strait moorings in Koenig, Provost, Sennéchael, et al., 2017). IBCAO bathymetry is in background color, with YP: Yermak plateau; SD: Sofia deep; HT: Hinlopen trough; KT: Kvitøya through; FVT: Franz-Victoria trough; BCT: British Channel trough.

$81^{\circ} \mathrm{N}$ following the $700 \mathrm{~m}$ isobath, and the Outer Yermak Branch follows the western side of the Yermak Plateau above the $1,000 \mathrm{~m}$ isobath. The hydrographic properties and strength of the branches vary over a broad range of time scales (with strong seasonal and interannual components). The branches merge again east of the Yermak Plateau in a complex yet unclear way to contribute to the Arctic Circumpolar Boundary Current which follows the continental slope around the deep Arctic Ocean basin (e.g. Crews et al., 2019; Hattermann et al., 2016; Koenig, Provost, Villacieros-Robineau, et al., 2017). To complicate further the picture, eddies have been observed in all branches (e.g. Athanase et al., 2019; Koenig, Provost, Sennéchael, et al., 2017; Våge et al., 2016).

Along the different paths, the AW is cooled and freshened as it melts the sea-ice, loses heat to the atmosphere and mixes with shelf waters (Rudels et al., 2015). West and north of Svalbard, the AW heat maintains ice-free conditions in winter in an area called the Whalers' Bay (e.g. Onarheim et al., 2014). Over the 1979-2014 period, the largest ice-free areas occurred during winter $2012 / 13$ with the ice edge located as far as $81^{\circ} \mathrm{N}, 32^{\circ} \mathrm{E}$ in January 2013 (Ivanov et al., 2016). In this period, particularly deep mixed layers (reaching $500 \mathrm{~m}$ ) were observed over the continental slope at $30^{\circ} \mathrm{E}$ (Pérez-Hernández et al., 2019; Renner et al., 2018). Within these deep mixed layers, AW became colder and fresher due to convective mixing. The resulting modified AW retained its properties as it was advected downstream. These were the first (and only so far) in-situ measurements documenting the formation and evolution of ventilated AW in the Western Nansen Basin (WNB). Waters modified through deep convection are the major contributors to the lower halocline waters (LHW) of the Arctic (Alkire et al., 2017; Rudels et al., 2004). 
Other processes contribute to the modification of the AW in the boundary current for example exchange with shelf waters and lateral eddy fluxes. The presence of troughs linking fjords to the continental slope west of Svalbard enhances shelf-slope exchange that cool and freshen the AW carried northward in the West Spitsbergen Current (Boyd \& D'Asaro, 1994; Goszczko et al., 2018; Koenig et al., 2018; Nilsen et al., 2016). Troughs north of Svalbard (Hinlopen, Kvitøya, Franz-Victoria and British Channel troughs; Figure 1) connect the Barents Sea to the deep western Nansen Basin. Schauer et al. (1997) showed that the shelf water draining from the Barents Sea via the troughs could significantly modify the core properties of the AW and influence the internal dynamics of the eastward current. Lind and Ingvaldsen (2012) focused on the variability and impacts of the AW entering the Barents Sea from the north between Svalbard and Franz Josef Land.

The AW boundary current has been shown to be unstable both west (e.g. von Appen et al., 2016) and north of Svalbard (e.g. Pérez-Hernández et al., 2017; Schauer et al., 1997) and spawn eddies as a result of barotropic and baroclinic instabilities. AW eddies are numerous in Fram Strait (e.g. von Appen et al., 2016), not uncommon in the WNB (e.g. Athanase et al., 2019; Cokelet et al., 2008; Våge et al., 2016) and are quite well represented in high-resolution models (e.g. Athanase et al., 2019; Appen et al., 2016; Crews et al., 2018; Hattermann et al., 2016; Wekerle et al., 2017). These warm core eddies enhance lateral exchange injecting AW from the slope into the deep basin (e.g. Våge et al., 2016).

In spite of recent efforts, observations in the area remain scarce and models are useful to provide a broader spatial and temporal context. The $1 / 12^{\circ}$ Mercator Ocean operational physical system has shown some skills in reproducing the hydrography, mesoscale structures and seasonal signals in the WNB (Athanase et al., 2019; Koenig, Provost, Sennéchael, et al., 2017; Koenig, Provost, Villacieros-Robineau, et al., 2017). The objective of this paper is to take advantage of 14 years of fields from the Mercator Ocean system to revisit AW modification along the continental slope north and northeast of Svalbard from synoptic to interannual scales, with a particular focus on AW ventilation through winter convection. Indeed, winter ventilation of the AW layer appears to be a rather localized phenomena in time and space as it requires near-surface AW inflow and appropriate atmospheric forcing (pushing the ice away and large negative heat fluxes) (Ivanov et al., 2018; Koenig, Provost, Sennéchael, et al., 2017; Renner et al., 2018). Hence, a model can be a useful tool to carry such a study. An important issue is to determine whether the deep mixed layers and intense AW ventilation episode documented in winter 2012/13 (Pérez-Hernández et al., 2019) was exceptional in the last decade, as Meyer et al. (2017) observed much shallower mixed layers in winter 2015.

We further evaluate the Mercator Ocean system performance by examining AW inflow at Fram Strait during five years and by comparing model outputs to various non-assimilated datasets in the WNB (Figure 1). The paper is structured as follows. Section 2 presents the Mercator Ocean operational system and independent observational data used to evaluate the model. The performance of the model in representing realistic AW inflow, properties, and winter ventilation processes in the WNB is examined in section 3. In section 4, locations and years of extreme deep mixed layers are investigated and corresponding deep convection is described. Other processes contributing to AW modification such as lateral exchange either with the Barents Sea via the troughs or with the offshore open ocean via the mesoscale eddies are examined in section 5. Results are summarized and discussed in section 6.

\section{Data}

\subsection{Mercator Ocean Operational System}

The $1 / 12^{\circ}$ global Mercator Ocean operational system (hereafter PSY4) was developed for the Copernicus Marine Environment Monitoring Service (CMEMS; http://marine.copernicus.eu/). A full description of the system components is available in Lellouche et al. (2018), and only some elements are presented here. The model component is based on the NEMO ocean model, with a $1 / 12^{\circ}$ ORCA grid type (i.e. horizontal resolution of $4 \mathrm{~km}$ in the WNB; Hu et al., 2019). The water column is composed of 50 vertical levels, with typically $1 \mathrm{~m}$ resolution at the surface decreasing to $450 \mathrm{~m}$ at the bottom and 22 levels within the upper $100 \mathrm{~m}$. The bathymetry used in the system is a combination of interpolated ETOPO1 (Amante \& Eakins, 2009) and GEBCO8 (Becker et al., 2009) databases. ETOPO1 datasets are used in regions deeper than $300 \mathrm{~m}$ and GEBCO8 is used in regions shallower than $200 \mathrm{~m}$ with a linear interpolation in the 200-300 m layer. The forcing atmospheric fields are obtained from the European Centre for Medium-Range Weather 
Table 1

Data used for model evaluation (number of profiles in the WNB area)

\begin{tabular}{|c|c|c|c|c|}
\hline Dataset & Parameters & Dates & Reference & Web site \\
\hline Fram Strait moorings & $\mathrm{T}, \mathrm{S}$ & January 2007 to October 2012 & Beszczynska-Möller et al. (2012) & https://doi.org/10.1594/PANGAEA.900883 \\
\hline F1 to F7 & $\begin{array}{l}\mathrm{U}, \mathrm{V} \\
*\end{array}$ & & & \\
\hline \multirow[t]{4}{*}{ A-TWAIN mooring array } & $\mathrm{T}, \mathrm{S}$ & September 2012 to & \multirow[t]{2}{*}{ Pérez-Hernández et al. (2019) } & WHOI moorings: \\
\hline & $\mathrm{U}, \mathrm{V}$ & September 2013 & & https://doi.org/10.18739/A2S569 \\
\hline & $* *$ & & \multirow[t]{2}{*}{ Renner et al. (2018) } & NPI moorings: \\
\hline & & & & https://doi.org/10.21334/npolar.2017.73d0ea3a \\
\hline UDASH database & $\mathrm{T}, \mathrm{S}$ & January 2007 to & \multirow[t]{3}{*}{ Behrendt et al. (2018) } & https://doi.pangaea.de/10.1594/ \\
\hline CTD \& ITP & 888 profiles & December 2015 & & PANGAEA.872931 \\
\hline IAOOS ITP & $\mathrm{T}, \mathrm{S}$ & & & \\
\hline 7,8 & 111 profiles & January to March 2015 & $\begin{array}{l}\text { Koenig, Provost, } \\
\text { Villacieros-Robineau, et al. (2017) }\end{array}$ & SEANOE: https://doi.org/10.17882/59516 \\
\hline 23,24 & 264 profiles & $\begin{array}{l}\text { April } 2017 \text { to } \\
\text { January } 2018\end{array}$ & Athanase et al. (2019) & SEANOE: https://doi.org/10.17882/57288 \\
\hline A-TWAIN & $\mathrm{T}, \mathrm{S}$ & & & \\
\hline \multirow[t]{2}{*}{ CTD } & 49 profiles & September 2012 & Våge et al. (2016) & \multirow[t]{2}{*}{ http://atwain.whoi.edu/ } \\
\hline & 167 profiles & September 2013 & Pérez-Hernández et al. (2017) & \\
\hline N-ICE 2015 & $\mathrm{~T}, \mathrm{~S}$ & & & \\
\hline CTD & 51 profiles & January to June 2015 & Meyer et al. (2017) & https://doi.org/10.21334/npolar.2017.92262a9c \\
\hline
\end{tabular}

*Number of profiles: See Figures 2 and $3{ }^{* *}$ TS profiles from MMPs: 1437 daily profiles; UV profiles from upper ADCPs: 2173 daily profiles

Forecasts-Integrated Forecast System (ECMWF-IFS) at 3-hr resolution, in order to reproduce the diurnal cycle. Observations assimilated in PSY4 are along-track satellite altimetry, sea surface temperature (OSTIA SST), in-situ vertical profiles of temperature and salinity, and OSI SAF sea-ice concentration. OSI SAF products are based on manual interpretation of a large set of high-resolution satellite data, including AMSR2 products (Advanced Microwave Scanning Radiometer 2, https://nsidc.org/data/). During the assimilation procedure, a particular treatment is applied to areas potentially covered with sea-ice: all observations errors in the multivariate SEEK filter increase linearly (less weight in the analysis) with the decrease of the SST from $-1{ }^{\circ} \mathrm{C}$ to $-1.7^{\circ} \mathrm{C}$ and the observations are rejected if SST is less than $-1.7^{\circ} \mathrm{C}$ (i.e. an approximation of the freezing point). In other words, apart from the sea ice concentration no other quantities are assimilated in ice-covered oceans. The PSY4 system starts in October 2006 from a "cold" start (initial currents are null) using initial climatological conditions from EN4.2.1 hydrographic temperature and salinity data (Good et al., 2013). Daily outputs from January 2007 to May 2020 are used in this paper.

\subsection{Non-assimilated Data Used for Model Evaluation}

Data used for the evaluation include temperature and salinity profiles from the UDASH database (Behrendt et al., 2018) plus recent observations (N-ICE 2015, A-TWAIN 2012/13 and IAOOS platforms), and mooring data (Figure 1, Table 1). From 1997 onwards, a mooring array has been maintained over the eastern slope of Fram Strait at $78.85^{\circ} \mathrm{N}$ by the Alfred Wegener Institute. Here we use the easternmost moorings F1 to F7 temperature, salinity, and current data (between $3.5^{\circ} \mathrm{E}$ and $9^{\circ} \mathrm{E}$ i.e. in the WSC core and offshore branch following Beszczynska-Möller et al., 2012) from 2007 (first full year available in PSY4) to 2012. The A-TWAIN mooring array, located between $81.4^{\circ} \mathrm{N}-31.2^{\circ} \mathrm{E}$ and $81.9^{\circ} \mathrm{N}-30^{\circ} \mathrm{E}$ (yellow stars on Figure 1), was maintained from 24 September 2012 to 15 September 2013 as part of the international project "Long-term variability and trends in the AW inflow region" (Table 1). The six A-TWAIN moorings provided current and hydrographic measurements in the boundary current north of Svalbard.

\section{Performance of the Mercator Ocean PSY4 System in the WNB}

Daily PSY4 fields were collocated in time and space (closest grid cell) with conservative temperature (CT) and absolute salinity (SA) profiles from drifting buoys and CTD stations. Model and in-situ profiles were interpolated to the same 2-m vertical resolution. Mooring measurements and the associated colocated model fields were 10-day low-pass filtered. 

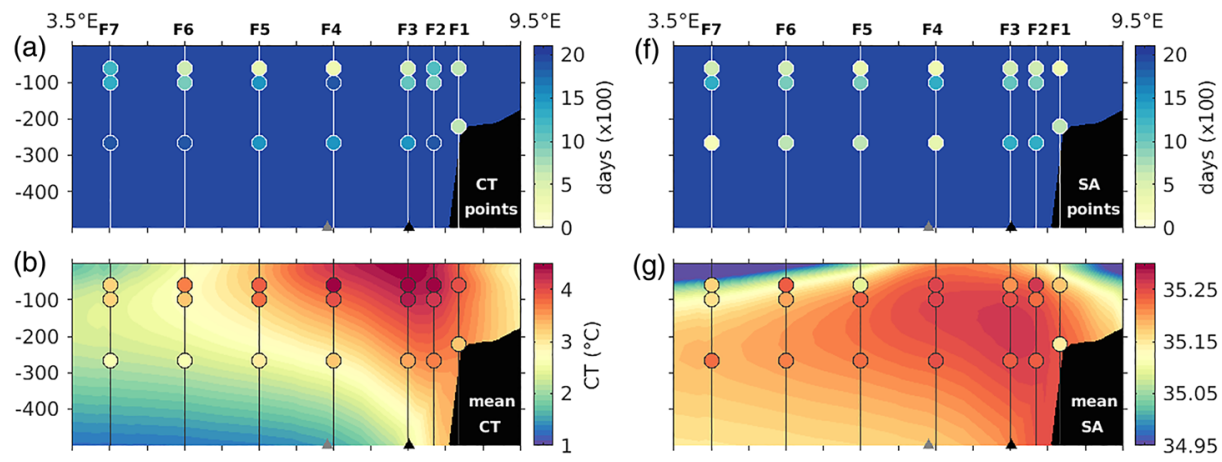

(g)
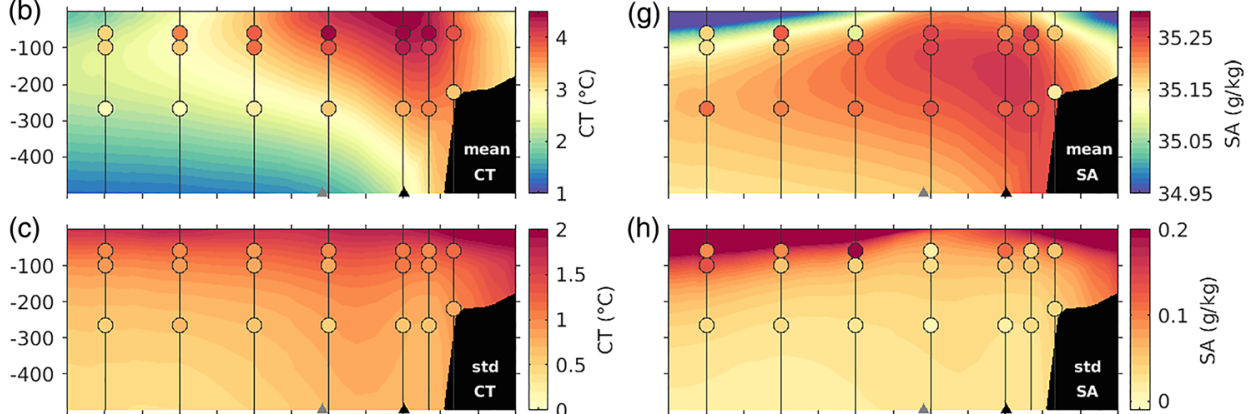

(d) $(e)$
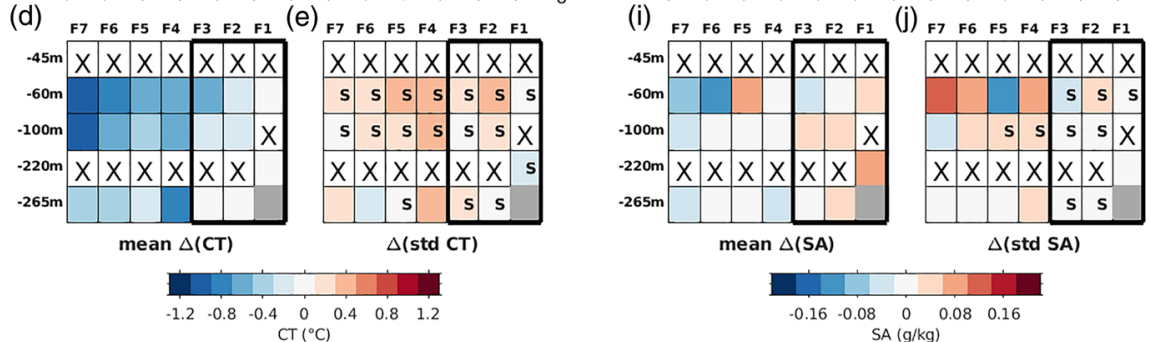

Figure 2. (a) Number of data points available over the 2007-2012 period in the model (background) and mooring observations (colored dots). Model fields cover 2,190 days, while moorings data coverage varies between 250 and 1990 days because of data gaps. (b) Mean conservative temperature (CT, ${ }^{\circ} \mathrm{C}$ ) over the 2007-2012 period and (c) associated STD, along the F1-F7 mooring array. Isobaths 1,000 and 1,500 $\mathrm{m}$ are marked by the black and gray triangles respectively. In (d) and (e), model fields have been collocated in time with observations. (d) Average model-observations differences of $\mathrm{CT}\left({ }^{\circ} \mathrm{C}\right)$ and (e) differences of STD in CT $\left({ }^{\circ} \mathrm{C}\right)$ for moorings F1 to F7 at different levels, over the 2007-2012 period. Gray cells indicate the continental shelf, crossed cells have no available data. 'S'-marked cells have model-observations correlation above the $90 \%$ confidence level. The thick black frame delineates cells in the West Spitsbergen current core as in Beszczynska-Möller et al. (2012). (f) To (j): Same for absolute salinity (SA, g/kg).

\subsection{AW Inflow at the Fram Strait Mooring Array}

For more precise comparisons, model fields were collocated in time and depth to match the number of available data points. The major difference in the mean was a cold and fresh bias in the upper $100 \mathrm{~m}$ offshore of the WSC core $\left(\Delta \mathrm{CT} \sim 0.6-1{ }^{\circ} \mathrm{C}, \Delta \mathrm{SA} \sim 0.08 \mathrm{~g} / \mathrm{kg}\right.$; Figures $\left.2 \mathrm{~d}, 2 \mathrm{i}\right)$. Modeled T-S fields showed standard deviations (STD) matching observations, in spite of larger values in the upper $100 \mathrm{~m}$ (Figures $2 \mathrm{c}, 2 \mathrm{e}, 2 \mathrm{~h}, 2 \mathrm{j}$ ). Overall, themooring array provided more velocity data days than temperature and salinity data days (Figures 3a, 3f; 2a, 2f). Modeled current speed fields were rather realistic for both zonal and meridional components, as detailed below (Figures 3b, 3c, 3g, 3h).

Within the WSC core (F1 to F3), the modeled temperature and salinity matched moorings data, with small differences (cold bias $\sim 0.4-0{ }^{\circ} \mathrm{C}, \Delta \mathrm{SA} \pm 0.08 \mathrm{~g} / \mathrm{kg}$; Figures $2 \mathrm{~d}, 2 \mathrm{i}$ ) and statistically significant correlation coefficients $\mathrm{r}(\mathrm{CT})$ and $\mathrm{r}$ (SA) (to the $90 \%$ confidence level) in the ranges 0.7-0.95 and 0.4-0.75 (respectively). Both meridional and zonal current velocities were well reproduced at F2 mooring location (Figures 3d, 3i). The modeled WSC core (defined as V > $15 \mathrm{~cm} / \mathrm{s}$, e.g. Beszczynska-Möller et al., 2012) was located slightly further offshore than in the observations and modeled meridional current velocities were $0.15 \mathrm{~m} / \mathrm{s}$ smaller $(0.05 \mathrm{~m} / \mathrm{s}$ larger) than observed ones at F1 (at F3) (Figure 3d). In the WSC, modeled velocities exhibited temporal variations of the right amplitude and were well correlated with observations, with statistically significant correlation coefficients in the range 0.4-0.7 for both components (S-marked cells in Figures 3e, 3j).

The offshore WSC branch, with larger vertical temperature gradient and meridional velocities between 0 and $15 \mathrm{~cm} / \mathrm{s}$ (e.g. Beszczynska-Möller et al., 2012), extends from 6.5 to $7.5^{\circ} \mathrm{E}$ (F4-F5) in the model, as in the 

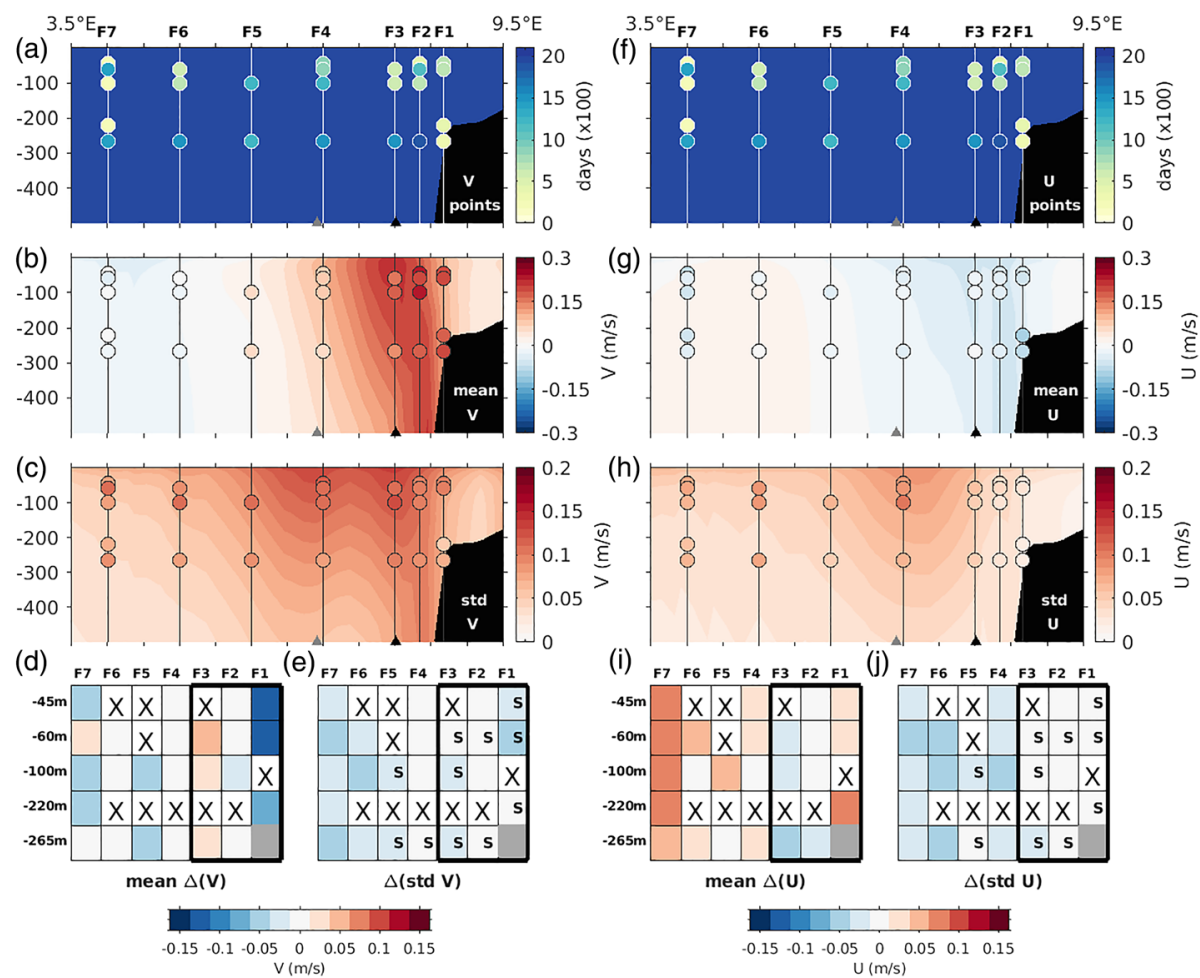

Figure 3. (a) Number of data points available over the 2007-2012 period in the model (background) and mooring observations (colored dots). Model fields cover 2,190 days, while moorings data coverage varies between 190 and 1960 days because of data gaps. (b) Mean meridional speed (V, m/s) over the 2007-2012 period and (c) associated STD, along the F1-F7 mooring array. Background colors correspond to model fields, colored dots to mooring data. In (d) and (e), model fields have been collocated in time with observations to take data gaps into account. Isobaths 1,000 and $1,500 \mathrm{~m}$ are marked by the black and gray triangles respectively. (d) Average model-observations differences of meridional speed V (m/s) and (e) differences of STD in V for mooring F1 to F7 at different levels, over the 2007-2012 period. Gray cells indicate the continental shelf, crossed cells have no available data. 'S'-marked cells have modelobservations correlation above the $90 \%$ confidence level. The thick black frame delineates cells localized in the WSC core as in Beszczynska-Möller et al. (2012). (f) To (j): Same for zonal speed (U, m/s).

observations (Figures 2b, 3b, Figure 2 in Beszczynska-Möller et al., 2012). The increased STDs between F3 and F4 locations in all parameters (Figures $2 \mathrm{c}, 2 \mathrm{~h}, 3 \mathrm{c}, 3 \mathrm{~h}$ ) likely marked the transition between the WSC core and this offshore branch. West of $6^{\circ} \mathrm{E}$, where the variable recirculation branches of the Fram Strait interior can be found (F6-F7), modeled velocities showed less variations than observations and correlations were less significant (S-marked cells in Figures 3e, 3j). The weak correlations in salinity at $65 \mathrm{~m}$ between F7 and F4 are found in a complex region, with variable ice cover and water properties (front migration).

In summary, PSY4 represented well the AW inflow properties, spatial structure and temporal variability. There was no seasonality in model-observation differences in the WSC core. To our knowledge, it was the first time that such a five year-long model validation was conducted at Fram Strait.

\subsection{Temperature-Salinity Profiles in the WNB}

Nearly 1,500 T-S profiles were gathered in the upper $750 \mathrm{~m}$ of the WNB over the 2017-2018 period (section 2, Figures 4a, 4f). The AW layer (such as $\mathrm{CT}>1{ }^{\circ} \mathrm{C}, \mathrm{SA}>35.05 \mathrm{~g} / \mathrm{kg}$ ) was on average located between 150 and $600 \mathrm{~m}$, with its core near $250 \mathrm{~m}$ (i.e. where temperature is maximum) both in model and observations (respectively red and black in Figure 4b). The model exhibited a cold and fresh bias in the 100-250 m layer (less than $0.5{ }^{\circ} \mathrm{C}$ and $0.04 \mathrm{~g} / \mathrm{kg}$; Figures 4c, 4e), as the modeled mean thermocline and halocline were too smooth and extended about $50 \mathrm{~m}$ too deep (Figures $4 \mathrm{~b}, 4 \mathrm{~d}$ ). AW properties in the 250-550 m layer were well reproduced (biases less than $0.2^{\circ} \mathrm{C}$ and $0.01 \mathrm{~g} / \mathrm{kg}$ ), with STDs similar in average profiles and T-S differences (shaded envelopes on Figures 4b, 4c). Below 600 m, the model shows a moderately warm and salty bias 
(a)

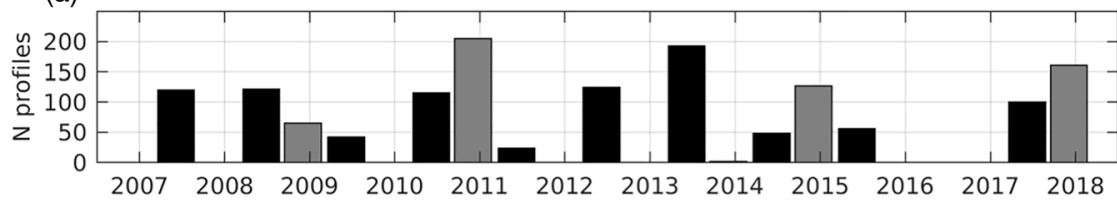

(b)

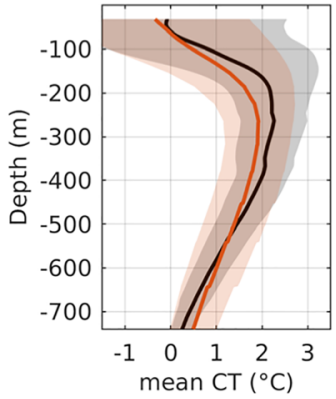

(c)

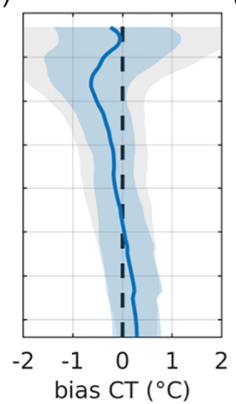

(d)

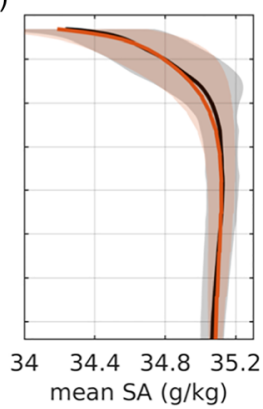

(e)

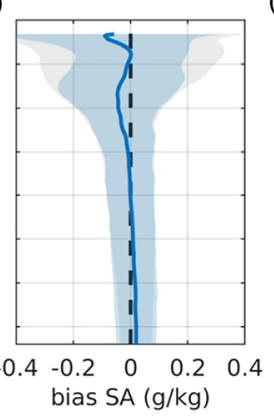

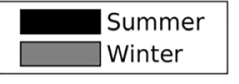

(f)

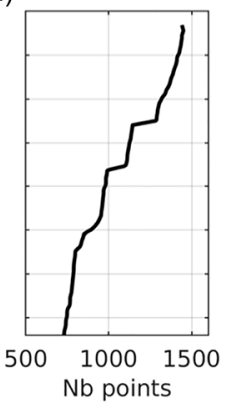

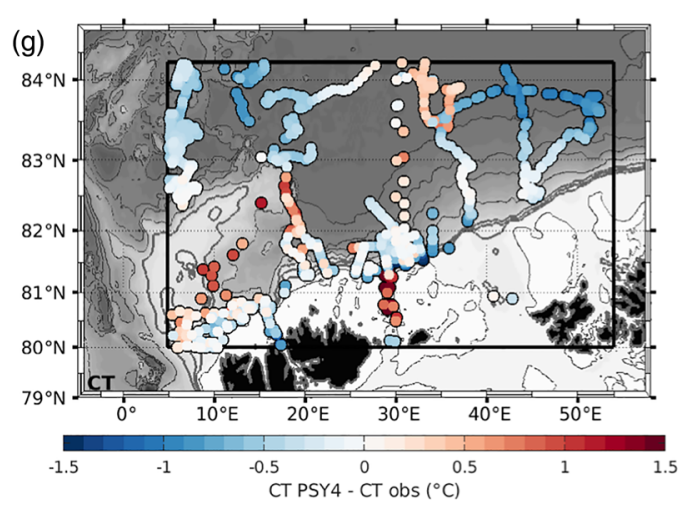

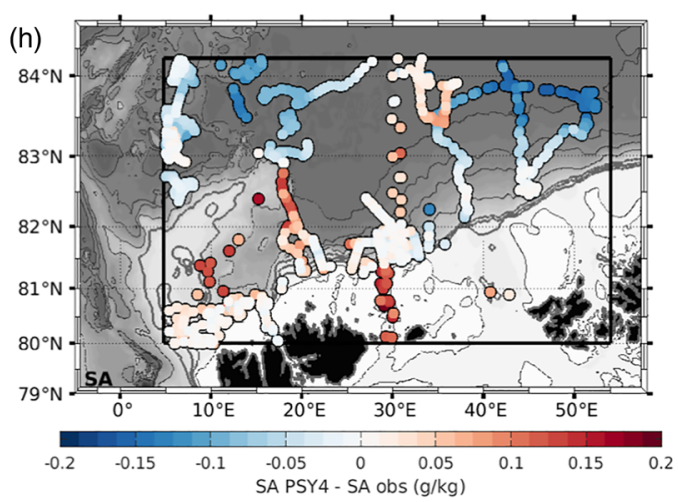

Figure 4. (a) Number of in-situ temperature and salinity profiles available in the Western Nansen Basin between 2007 and 2018 from CTD stations and ITPs (see Table 1). (b) Mean conservative temperature (CT, ${ }^{\circ} \mathrm{C}$ ) profile in observations (black) and the collocated model outputs (red) over the $2007-2018$ period (thick lines). Shaded envelopes are STD around the mean (observations in gray, light red for model). (c) Model-observations difference of mean CT ( $\left.{ }^{\circ} \mathrm{C}\right)$. Shaded envelopes are the bias STD (blue) and the sum of model and observations STDs (gray) at each level. (d-e) Same for absolute salinity (SA, g/kg). (f) Number of data points available at each level, for observations and colocated model profiles. (g) Model-observations differences at $265 \mathrm{~m} \mathrm{in} \mathrm{CT}\left({ }^{\circ} \mathrm{C}\right)$ and $(\mathrm{h}) \mathrm{SA}(\mathrm{g} / \mathrm{kg})$.

(e.g. $+0.25{ }^{\circ} \mathrm{C}$ and $+0.02 \mathrm{~g} / \mathrm{kg}$ at $700 \mathrm{~m}$, Figures $4 \mathrm{c}, 4 \mathrm{e}$ ). This is likely explained by the model vertical resolution which decreases with depth (1-m thick layers near the surface, 19-m thick at the layer centered at $109 \mathrm{~m}$, and 130-m thick at the $763 \mathrm{~m}$ layer). Nonetheless, at $265 \mathrm{~m}$ (near the AW core), modelobservation differences were small along the slope in the AW boundary current $\left(\Delta \mathrm{CT} \sim 0\right.$ to $-0.2^{\circ} \mathrm{C}$, $\Delta \mathrm{SA} \sim \pm 0.03 \mathrm{~g} / \mathrm{kg}$; Figures $4 \mathrm{~g}$ and $4 \mathrm{~h}$ ). STD envelopes around mean profiles are of the same order of magnitude in PSY4 and in observations (Figures $4 \mathrm{~b}$ and $4 \mathrm{~d}$ ). The bias envelope (root mean squared difference, light blue in Figures $4 \mathrm{c}$ and $4 \mathrm{e}$ ) is smaller than the square-root of the sum of model and observations variances (light gray in Figures $4 \mathrm{c}$ and $4 \mathrm{e}$ ), illustrating the model skills.

Overall, PSY4 well represented the temperature and salinity in the AW layer in spite of a cold bias $\left(\Delta \mathrm{CT} \sim 0.2^{\circ} \mathrm{C}\right)$. We now examine the model performance in reproducing two sources of AW modification in the WNB: shelf-basin exchange and winter convective mixing.

\subsection{Shelf-Basin Exchange in the Model}

Both west and north of Svalbard, PSY4 reproduced circulation patterns described by Nilsen et al. (2016) and Pérez-Hernández et al. (2017): modeled warm and salty AW entered the troughs along their southern (or western, respectively) edge and cooled down and freshened as it flowed cyclonically along the edges of the troughs (Figure 5).

We illustrated shelf-basin exchange west of Svalbard with model temperature, salinity and velocity fields in late July 2017, a time of northerly or weak winds, allowing waters accumulated on the shelf during strong 

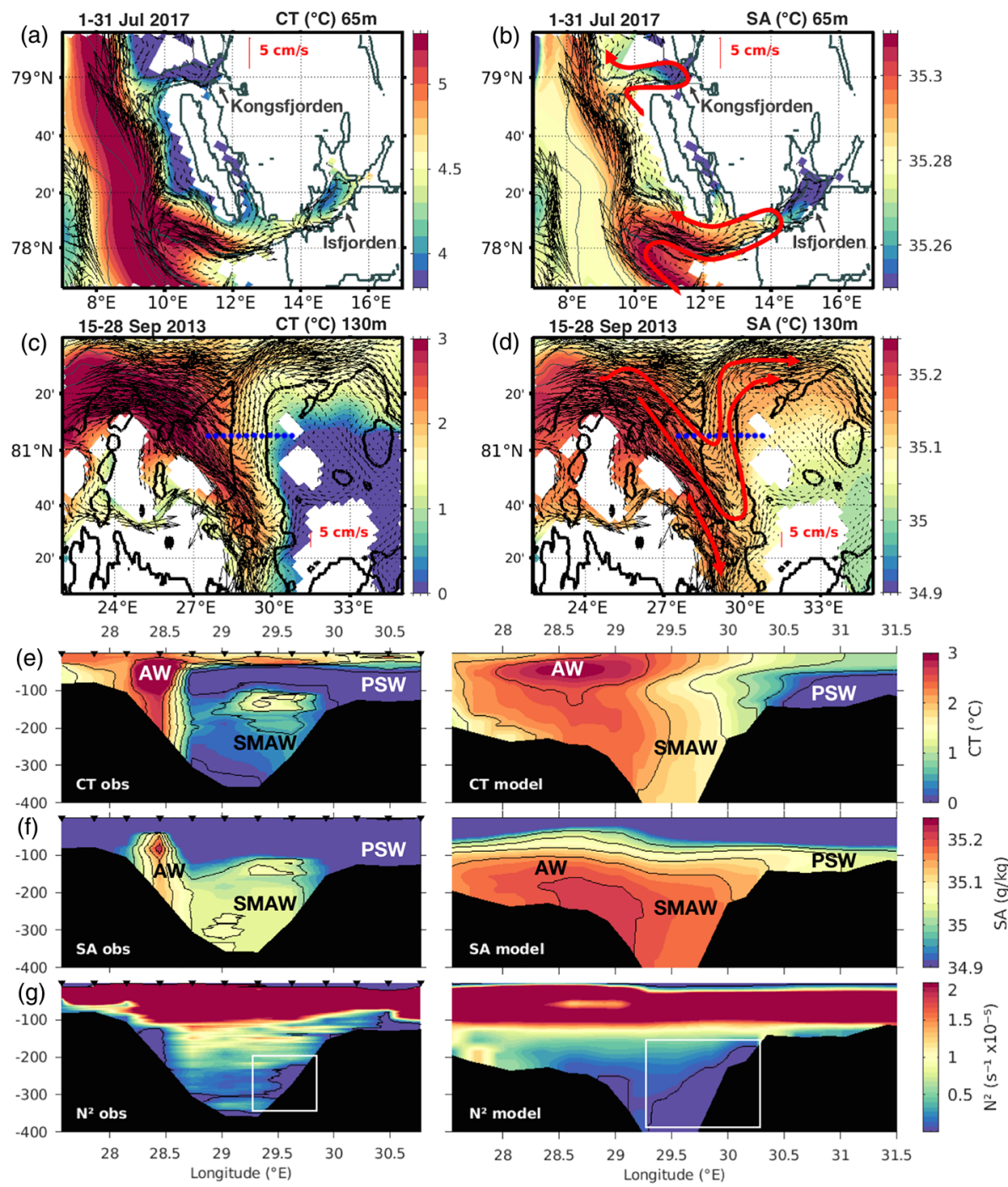

Figure 5. (a) Conservative temperature $\left({ }^{\circ} \mathrm{C}\right)$ and (b) absolute salinity $(\mathrm{g} / \mathrm{kg})$ fields from PSY4 at $65 \mathrm{~m}$ west of Svalbard in late July 2017 (at the time of the observations from Koenig et al., 2018). When velocities (arrows) were larger than $12 \mathrm{~cm} / \mathrm{s}$, arrows were removed for sake of clarity. Red arrows schematize the circulation in Kongsfjorden and Isfjorden (from Nilsen et al., 2016). (c) Conservative temperature $\left({ }^{\circ} \mathrm{C}\right)$ and (d) absolute salinity $(\mathrm{g} / \mathrm{kg}$ ) fields from PSY4 at $130 \mathrm{~m}$ over the Kvitøya trough region located north-east of Svalbard in late September 2013 (at the time of the observations from Pérez-Hernández et al., 2017; blue dots). Velocities as in (a), (b). The $200 \mathrm{~m}$ isobath (thick black line) from IBCAO shows a narrow entrance and a north-south orientation. In the model, the Kvitøya trough mouth is too large and its main axis is tilted to the west (see Figure A1). (e), (f), (g) cross sections of conservative temperature $\left({ }^{\circ} \mathrm{C}\right.$ ), absolute salinity $(\mathrm{g} / \mathrm{kg})$ and brunt-Väisälä frequency $\mathrm{N}^{2}\left(\mathrm{~s}^{-1}\right)$. Left panels are from observations (blue dots), right panels are from PSY4. The white box in (g) highlights the low- $\mathrm{N}^{2}$ water getting out of the trough. AW: Atlantic water; SMAW: Shelfmodified Atlantic water; PSW: Polar surface water.

southerly winds in early July to flow back down the slope (Koenig et al., 2018; Figure 5a, 5b). AW from the WSC that circulated in the troughs was mixed with fresher and much colder waters from the shelf as discussed in the literature (e.g., Nilsen et al., 2016). The cross-shelf exchange signal seen in Koenig et al. (2018) as small cold and fresh lenses (less than $10 \mathrm{~km}$ wide) with high particle concentrations, lay at the limit of the PSY4 resolution (4 km in the area). However, the model produced cold and fresh water patches coming out of the fjords in accordance with the wind forcing (not shown).

North of Svalbard, the model bathymetry (see appendix) does not accurately follow the Arctic region-dedicated IBCAO bathymetry (Jakobsson et al., 2012) in Kvitøya Trough: the trough entrance is too wide (western bank too deep) and the trough axis is tilted to the West (Figures 5c, 5d, and A1). This locally imprecise 

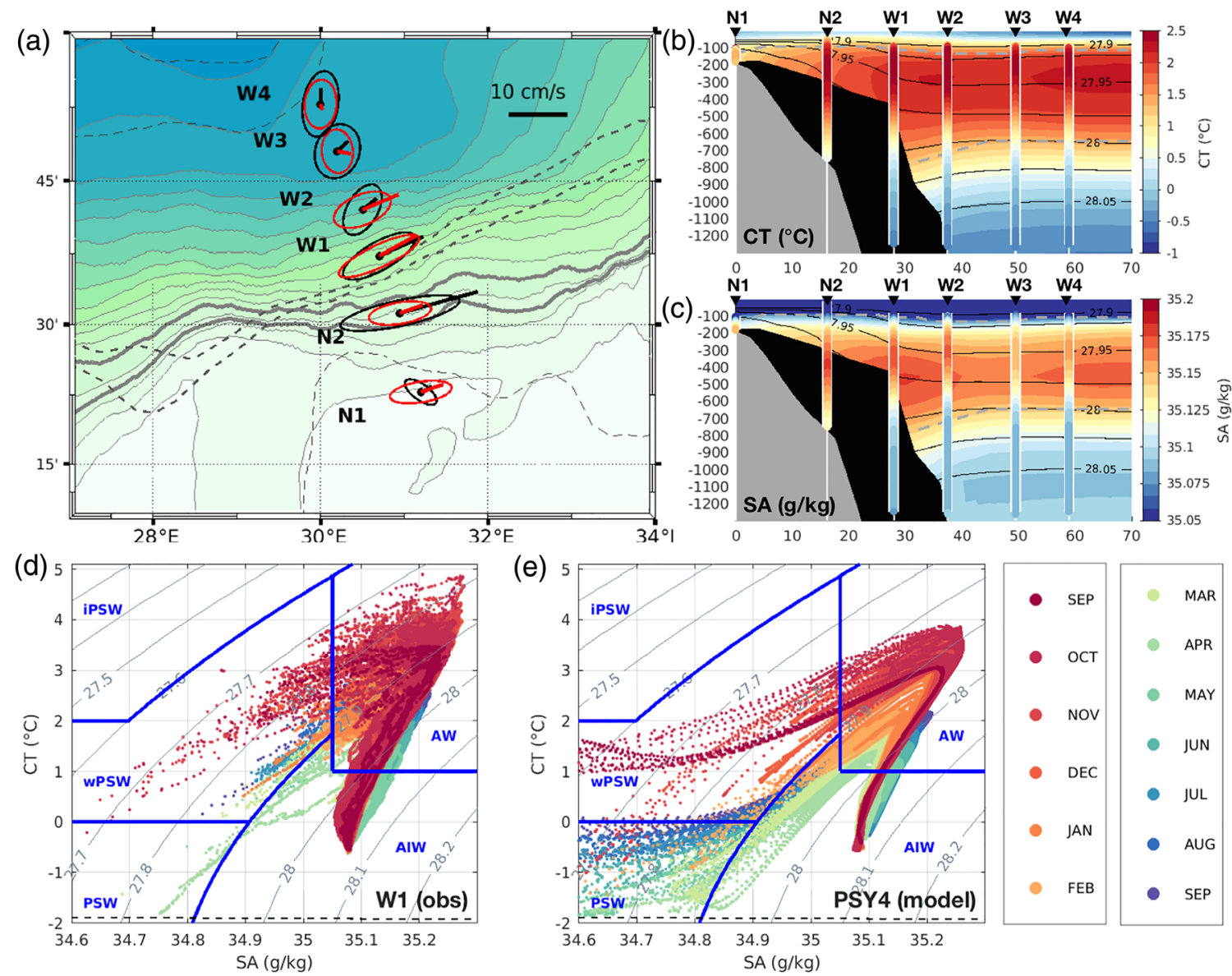

Figure 6. (a) Year-long current velocity averaged over the upper $70 \mathrm{~m}$, together with their variance ellipses, at the A-TWAIN mooring sites. Observations from acoustic Doppler current profilers are in black, collocated model outputs in red. IBCAO bathymetry is in background color with isobaths 700 and $1,000 \mathrm{~m}$ in thick gray lines. Dashed lines are model isobaths (200 m on the western flank of Kvitøya trough, 700 and 1,000 $\mathrm{m}$ in thick lines, 3,200 and 3,200 $\mathrm{m}$ offshore matching IBCAO isobaths, see Figure A1). (b) Year-long averages of conservative temperature $\left(\mathrm{CT},{ }^{\circ} \mathrm{C}\right)$ and (c) absolute salinity (SA, g/kg) at the a-TWAIN mooring sites (indicated as N for NPI and W for WHOI moorings), from the model (background color) and mooring data (vertical profiles bordered in white). IBCAO bathymetry is in gray, model bathymetry in black. Isopycnals (black contours) are plotted from 27.9 to $28.05 \mathrm{~kg} / \mathrm{m}^{3}$ every $0.025 \mathrm{~kg} / \mathrm{m}^{3}$. Dashed gray lines are the AW layer limits. (d) CT-SA diagram using WHOI-1 data from September 2012 to September 2013 (no data above $100 \mathrm{~m}$ depth). Months are in colors. (e) Same using collocated PSY4 CT and SA. Water mass boundaries are adapted from Pérez-Hernández et al. (2019), with AW such as CT $>1{ }^{\circ} \mathrm{C}$ and SA > 35.05 g/kg (i.e. 34.9 psu). AW: Atlantic water; AIW: Arctic intermediate water; PSW: Polar surface water; wPSW: Warm polar surface water; iPSW: Inshore polar surface water.

bathymetry is likely responsible for the salty and warm biases observed in Kvitøya Trough at $265 \mathrm{~m}$ (Figures 4g, 4h). Nevertheless, the model showed some skill. The comparison to the K2 section from Pérez-Hernández et al. (2017) showed AW entering the western flank of the trough, being cooled down and freshened through mixing with the cold, fresh Polar Surface Water (PSW, Figures 5e, 5f) from the shelves. The shelf-modified AW (hereafter SMAW, Figures 5e, 5f) circulated back towards the AW boundary current (difference in SMAW salinity between observations and model of $0.1 \mathrm{~g} / \mathrm{kg}$ ). These SMAW, injecting anomalously cold, fresh water into the AW boundary current, are vertically homogeneous and marked by a particularly low value of Brunt-Väisälä frequency $\left(\mathrm{N}^{2}<10^{-6}\right.$, Figure $\left.5 \mathrm{~g}\right)$. In the model part of the AW entering Kvitøya trough continued southward, towards the Barents Sea, in agreement with the observations (Figure 5c, 5d).

\subsection{Comparisons to the $30^{\circ} \mathrm{E}$ A-TWAIN Moorings}

The A-TWAIN mooring array provided a unique dataset documenting deep mixed layers and intense AW ventilation during winter 2012/13 (Pérez-Hernández et al., 2019). Modeled mean current velocities were of the same order of magnitude as the observations with similar directions (Figure 6a). The modeled AW jet was located further offshore than in the observations in Figure 6a, as the slope in the model 

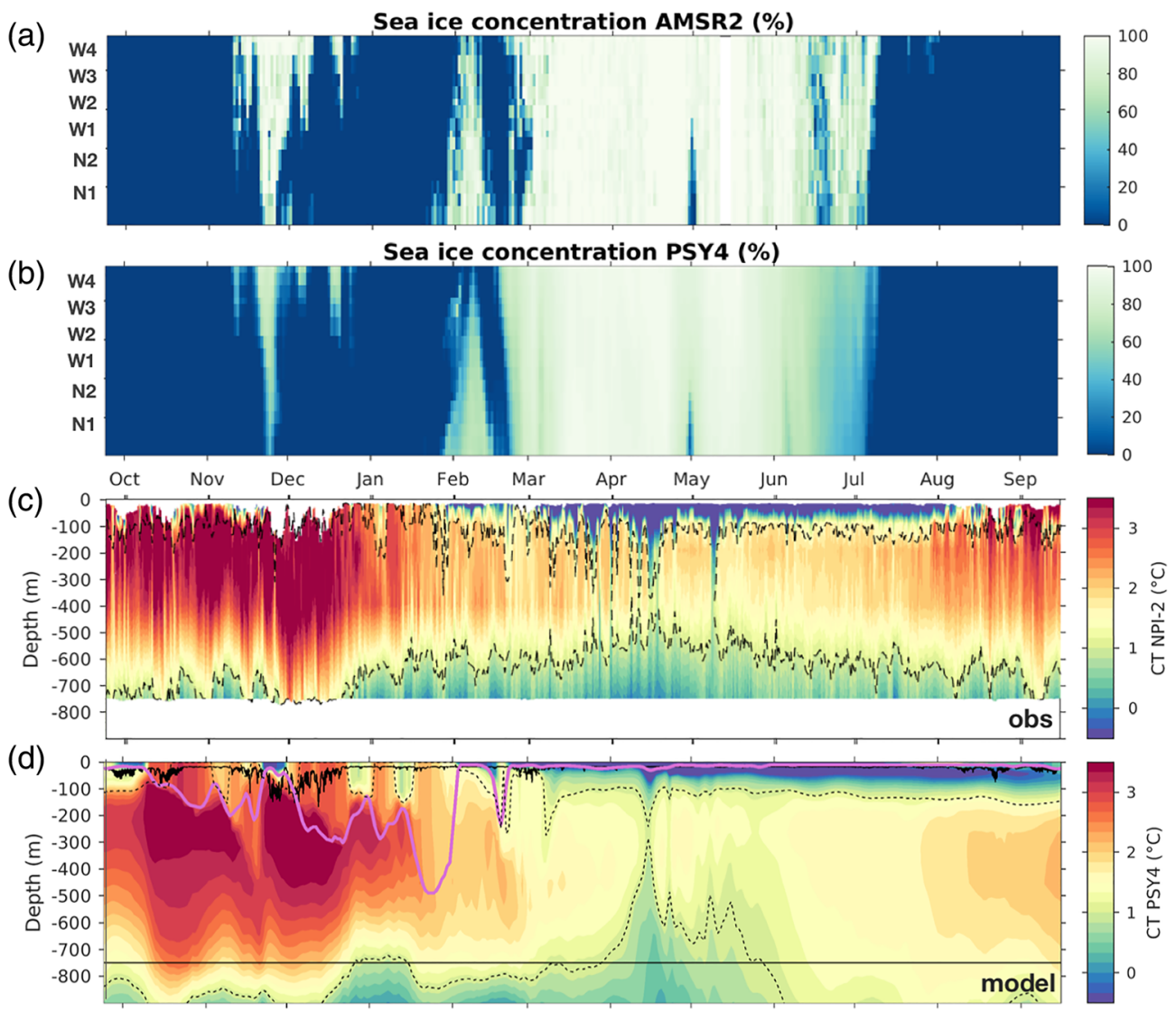

Figure 7. (a) AMSR2 sea-ice concentration (\%, in colors) along the A-TWAIN array (y-axis) from September 2012 to September 2013. (b) Same for PSY4. (c) Time-depth conservative temperature (CT, $\left.{ }^{\circ} \mathrm{C}\right)$ from mooring NPI-2 data. (d) Collocated modeled conservative temperature $\left(\mathrm{CT},{ }^{\circ} \mathrm{C}\right)$.Dashed lines in (c) and (d) mark the top and bottom boundaries of the AW layer (defined as in Figure 6). In (d), the purple line indicates the MLD estimate provided by the Mercator Ocean system, defined as the depth where density exceeds the surface density by $0.01 \mathrm{~kg} / \mathrm{m}^{3}$, while the black lines show the vertical extent of the mooring data (variable near surface due to blow-downs).

bathymetry was about $15 \mathrm{~km}$ too far north (isobath $700 \mathrm{~m}$ in Figures 6a-c, A1). As a result, maximal velocities were found at the WHOI-1 and WHOI-2 locations and not at NPI-2 and WHOI-1 as in the observations. Offshore of the modeled AW jet, at WHOI-3 and WHOI-4 currents exhibited smaller variations than in-situ data (major axis of $3 \mathrm{~cm} / \mathrm{s}$ instead of $4.5 \mathrm{~cm} / \mathrm{s}$ ). Note that current mean and variance were well reproduced at WHOI-1. Modeled AW salinity and temperature (Figures 6b-6e) were similar to the observations presented in Renner et al. (2018) and Pérez-Hernández et al. (2019). In the 100-500 m layer, biases in CT and SA did not exceed $0.5^{\circ} \mathrm{C}$ and $0.05 \mathrm{~g} / \mathrm{kg}$ respectively (not shown), and reproduced the observed seasonal variations (Figures $6 \mathrm{~d}, 6 \mathrm{e}$ ).

Modeled sea-ice matched AMSR2 3.125-km resolution satellite ice product (https://nsidc.org/data/) very well, both in cross-slope distribution and temporal evolution (Figures 7a, 7b; recall that PSY4 assimilates sea-ice concentration data). The evolution of temperature and salinity was well reproduced (example CT at NPI-2, Figures 7c, 7d), although the modeled AW layer ( $\mathrm{CT}>1{ }^{\circ} \mathrm{C}$ ) extended $\sim 150 \mathrm{~m}$ deeper than in the A-TWAIN mooring observations, likely due to the model vertical resolution (as mentioned in section 3.2). Pérez-Hernández et al. (2019) have documented deep mixed layers along the continental slope during winter 2012/13, likely formed by local winter convection and ventilating the AW layer. The model accurately reproduced the deepening of the mixed layer in November-December, resulting in particularly deep mixed layers ( 450 to $500 \mathrm{~m}$ ) in January 2013, with MLDs matching observations (Figure 7d; Figure 10 in Pérez-Hernández et al., 2019). A-TWAIN mooring observations showed for the first time that even after local convection ceased, the AW remained anomalously cold and fresh until the end of the moorings record, likely due to the advection of ventilated AW from upstream. Such behavior was also reproduced 
in PSY4, confirming the capability of the model in representing local winter convection and AW ventilation in the WNB (Figures 7c-d).

\section{Aw Ventilation in the WNB: Insights From 14 Years of PSY4 Fields}

The good performance of PSY4 in representing the AW ventilation in the WNB being assessed, we examined deep mixed layers formation and AW modification in a broader spatio-temporal context, using 14 years of PSY4 over the WNB.

\subsection{Identifying Extreme Mixed Layer Depths in the WNB Over 2007-2020}

The mixed layer depth (MLD) was defined as the shallowest depth at which potential density exceeded the surface value by $0.01 \mathrm{~kg} / \mathrm{m}^{3}$ (Boyer Montégut et al., 2004; Peralta-Ferriz \& Woodgate, 2015). We called maximum MLD the deepest MLD reached at each grid point every year, from June 1 of one year to May 31 of the following year. This time frame is chosen in order to avoid splitting the winter period into two time-series. Therefore, we obtain 13 year-long time spans from 2007/08 to 2019/20.

At each location, we obtained time-series of yearly maximum MLD and noted the associated sea-ice cover at the time of each detected maximum MLD. The largest 13-year average maximum MLDs ( $>300 \mathrm{~m}$ ) were found over the continental slope following the lateral extent of the AW boundary current, with an associated sea-ice cover lower than 40\% (Figures 8a and 8c). In this area, stds of maximum MLDs over the 13 years exceeded $200 \mathrm{~m}$ and corresponded to the largest ice cover stds in the area (above 40\%) (Figures $8 \mathrm{~b}$ and $8 \mathrm{~d}$ ).

Examination of years in which maximum MLDs were reached over the 2007-2020 period revealed two major signals (Figure 8e). Year 2012/13 (red area on Figure 8e) exhibited the deepest MLDs over the 13 years nearly everywhere east of $24^{\circ} \mathrm{E}$ and north-northeast of Yermak Plateau. Year 2017/18 (blue area on Figure 8e) was also highlighted with the deepest modeled MLDs over Yermak Plateau and Sofia Deep (west of $24^{\circ} \mathrm{E}$ ). In contrast, winters 2014/15 and 2010/11 were the mildest in terms of winter mixed layer depths (purple and yellow areas in Figure 8f). Time series of MLDs averaged over boxes A and B (defined in Figure 8) confirmed that these extreme winters (deepest and shallowest MLDs) stood out in the 13 years (Figures 9e, 9j).

A striking change in sea-ice cover, net atmospheric heat fluxes, upper ocean temperatures (10 and $50 \mathrm{~m}$ ), and MLDs occurred in 2011 in both boxes (Figures 9). Prior to 2011, there were no open ocean conditions (Figures 9a, 9f); ocean temperatures at 10 and $50 \mathrm{~m}$ were mostly below $0{ }^{\circ} \mathrm{C}$ (Figures 9d, 9i) and winter air temperatures below $-15^{\circ} \mathrm{C}$ (Figures $9 \mathrm{c}, 9 \mathrm{~h}$ ); annual cycles in heat fluxes and MLDs were rather regular, with heat fluxes mostly above $-150 \mathrm{~W} / \mathrm{m}^{2}$ and MLDs not exceeding $\sim 100 \mathrm{~m}$ (Figures 9c, e, h, j).

From 2012 onward, interannual variability increased with occurrences of open ocean conditions (Figures 9a, f). At $10 \mathrm{~m}$, ocean temperatures exceeded $0{ }^{\circ} \mathrm{C}$ in the absence of ice cover and returned to freezing temperatures under sea-ice, thus exhibiting a striking increase in variability after 2011 (Figures 9d, 9i). A clear trend in ocean temperatures at $50 \mathrm{~m}$ was observed $\left(\sim+0.21{ }^{\circ} \mathrm{C} /\right.$ year in box A i.e. northern Yermak Plateau; $+0.09{ }^{\circ} \mathrm{C} /$ year in box B i.e. continental slope). The smaller trends in temperature at 10 and $265 \mathrm{~m}$ (between 0.03 and $0.08{ }^{\circ} \mathrm{C} /$ year) were only marginally significant (to the $90 \%$ confidence level. After 2011, 50-m ocean temperatures remained above $0{ }^{\circ} \mathrm{C}$ over the continental slope and even around $2{ }^{\circ} \mathrm{C}$ over Yermak Plateau, while winter air temperatures exceeded $-15{ }^{\circ} \mathrm{C}$ (Figures 9d, 9i). However, over Yermak Plateau MLDs seldomly exceeded $100 \mathrm{~m}$ except for winter 2012/13 (reaching $180 \mathrm{~m}$ ) and the exceptional winter 2017/18 with MLD exceeding $300 \mathrm{~m}$ (examined in section 4.2; Figure 9e). In contrast, on the continental slope the change in 2011 was clear-cut in MLD amplitude and net atmospheric heat fluxes range (Figures 9i, 9j).

Through the 13 winters, large variations in air temperature were observed (Figures 9c, 9h). They were associated with storms passing by and favored upper ocean mixing.

During winter 2010/11, MLDs shallower than $70 \mathrm{~m}$ coincided with an ice cover greater than $80 \%$, and weak negative heat fluxes $\left(>-50 \mathrm{~W} / \mathrm{m}^{2}\right)$ in the two areas (Figure 9). Ocean temperatures at $50 \mathrm{~m}$ were around $0{ }^{\circ} \mathrm{C}$ (Figures 9d, 9i). In contrast, large winter MLDs (>200 m) were observed after 2011 (winters 2012/13 and 2017/18, red and blue shades in Figure 9) and corresponded to open ocean conditions with winds pushing the ice away (examples in Figures 10a, 10c) and large negative heat fluxes $\left(<-200 \mathrm{~W} / \mathrm{m}^{2}\right)$. Temperatures at $50 \mathrm{~m}$ exceeded $1^{\circ} \mathrm{C}$ at the beginning of winter (Figures $9 \mathrm{~d}, 9 \mathrm{i}$ ). In the highly variable post-2011 period, the 

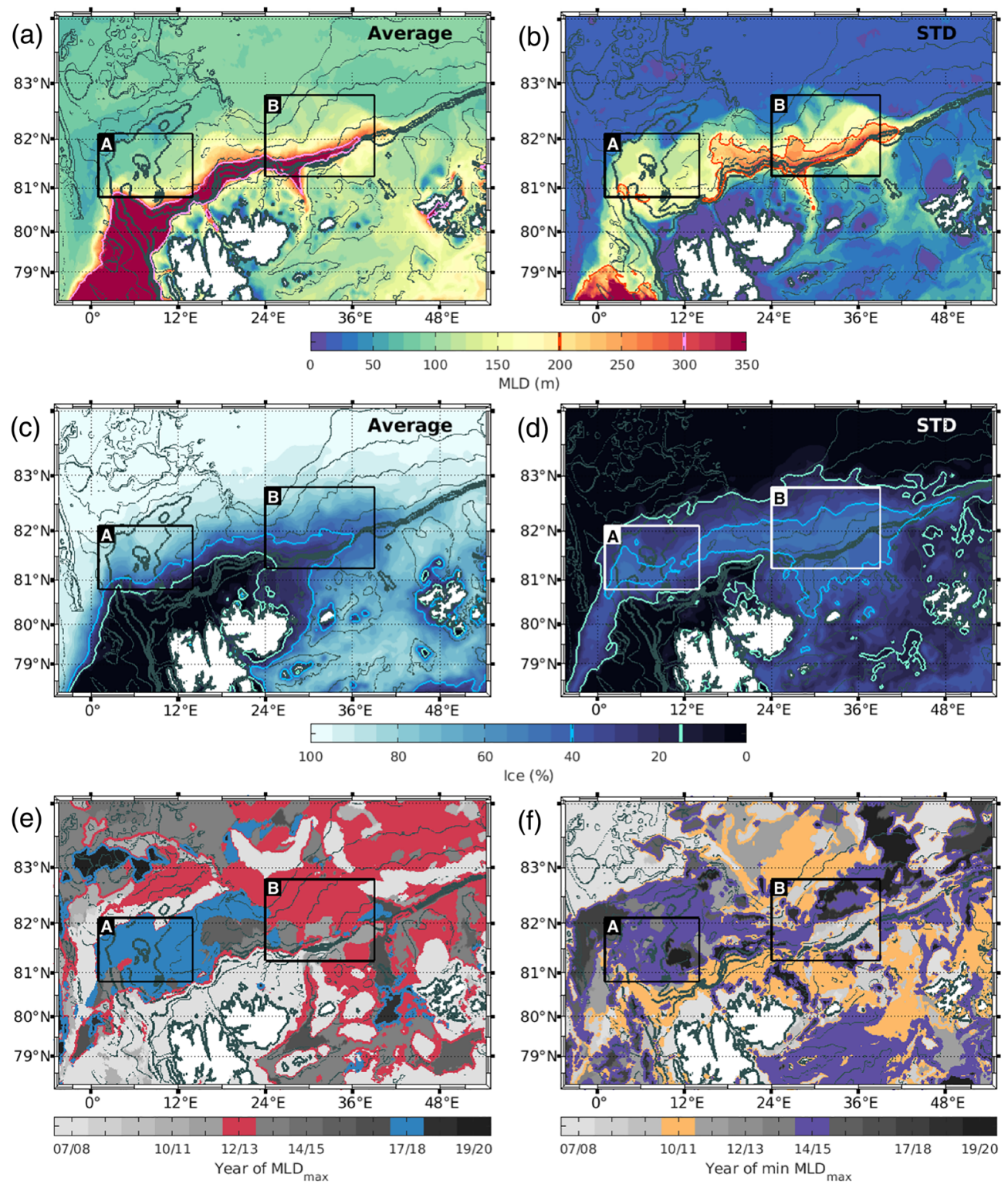

Figure 8. (a) Mean over 13 years of the annual mixed layer depth (MLD) maxima (in $m$ ) at each point and (b) its interannual STD. (c) Mean over 13 years of the ice cover (\%) on the date of the annual MLD maximum at each point and (d) interannual STD. (e) Year of the maximum MLD at each point over the 2007-2020 period. (f) Year when the annual maximum of MLD was the smallest at each point. Light pink contours delineate areas where $\mathrm{MLD}_{\max }>300 \mathrm{~m}$ (a); red contour areas where std $\left(M L D_{\max }\right)>200 \mathrm{~m}(\mathrm{~b})$; green and cyan contours are respectively the 15 and $40 \%$ ice cover limit (c, d). Year-long time spans were taken from June to may (included) of the following year. Time-series of several parameters averaged over boxes a and B are shown in Figure 9.

2014/15 winter stood out as a rather moderate MLD year in both boxes (Figure 9, purple shade) with a high percentage in ice cover and remarkably weak heat fluxes (Figures 9b-d, 9g-i). Over Yermak Plateau (box A), mixed layers also remained shallow in winters 2016/17, 2018/19 and 2019/20, as atmospheric conditions (wind direction and few storms) maintained a significant ice cover (Figures 9a-b, 9e). Model fields suggested that the particularly deep MLDs in winters 2012/13 and 2017/18 shoaled drastically when winds imported sea-ice and meltwater in the respective areas (Figures 9, 10b, 10d).

In summary, deep MLDs (>100 m) did not occur between 2007 and 2011. They are occasionally observed from 2012 onwards, with two exceptional winters in terms of deep convection: 2012/13 and 2017/18. 


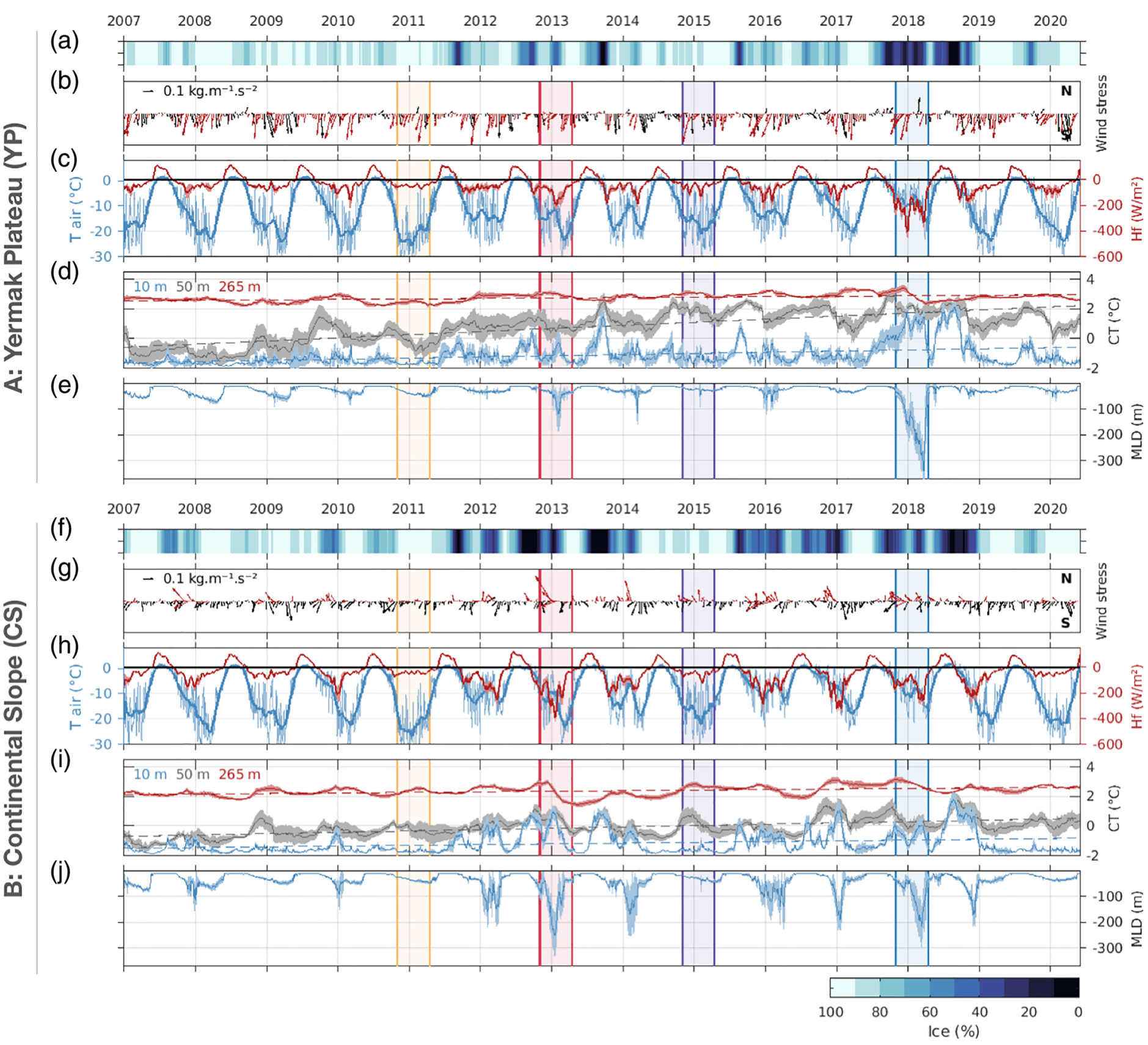

Figure 9. Spatially averaged time series over boxes a (Yermak plateau) and B (continental slope) from Figure 8. (a, f) ice cover (\%). (b, g) wind stress (kg.M ${ }^{-1} \cdot \mathrm{S}^{-2}$ ), favorable to ice-free conditions in red (easterlies for a and southeasterlies for B). (c, h) net total heat flux $\left(\mathrm{W} / \mathrm{m}^{2}\right)$ and air temperature at $2 \mathrm{~m}\left({ }^{\circ} \mathrm{C}\right.$, blue), 3 -month low-pass filtered (thick blue line). (d, i) conservative temperature in the ocean $\left({ }^{\circ} \mathrm{C}\right.$ ) at $10 \mathrm{~m}$ (blue), $50 \mathrm{~m}$ (gray) and $265 \mathrm{~m}$ (red) (linear trends in dashed lines). (e, j) mixed layer depth (MLD, m). Shaded envelopes are spatial stds over the boxes. Vertical lines highlight winters selected in Figures 8e and 8f. Wind velocities and net total heat fluxes are low-pass filtered with a 1-month cut-off. For sake of clarity, wind arrows are plotted every 10 days.

\subsection{Winter 2017/18 Over Yermak Plateau}

The oceanic heat carried by warm near-surface AW is responsible for the quasi-perennial ice-free conditions as far north as $81^{\circ} \mathrm{N}$ in an area called Whalers' Bay, located northwest of Svalbard (e.g. Onarheim et al., 2014). Winter $2017 / 18$ exhibited open ocean conditions up to $82.5^{\circ} \mathrm{N}$ over the Yermak Plateau, associated with deep mixed layers exceeding $300 \mathrm{~m}$ (Figures 11a-b). The development of these exceptional deep mixed layers coincided with the presence of warm near-surface AW (above $3{ }^{\circ} \mathrm{C}$ in early-winter) reaching as far as 

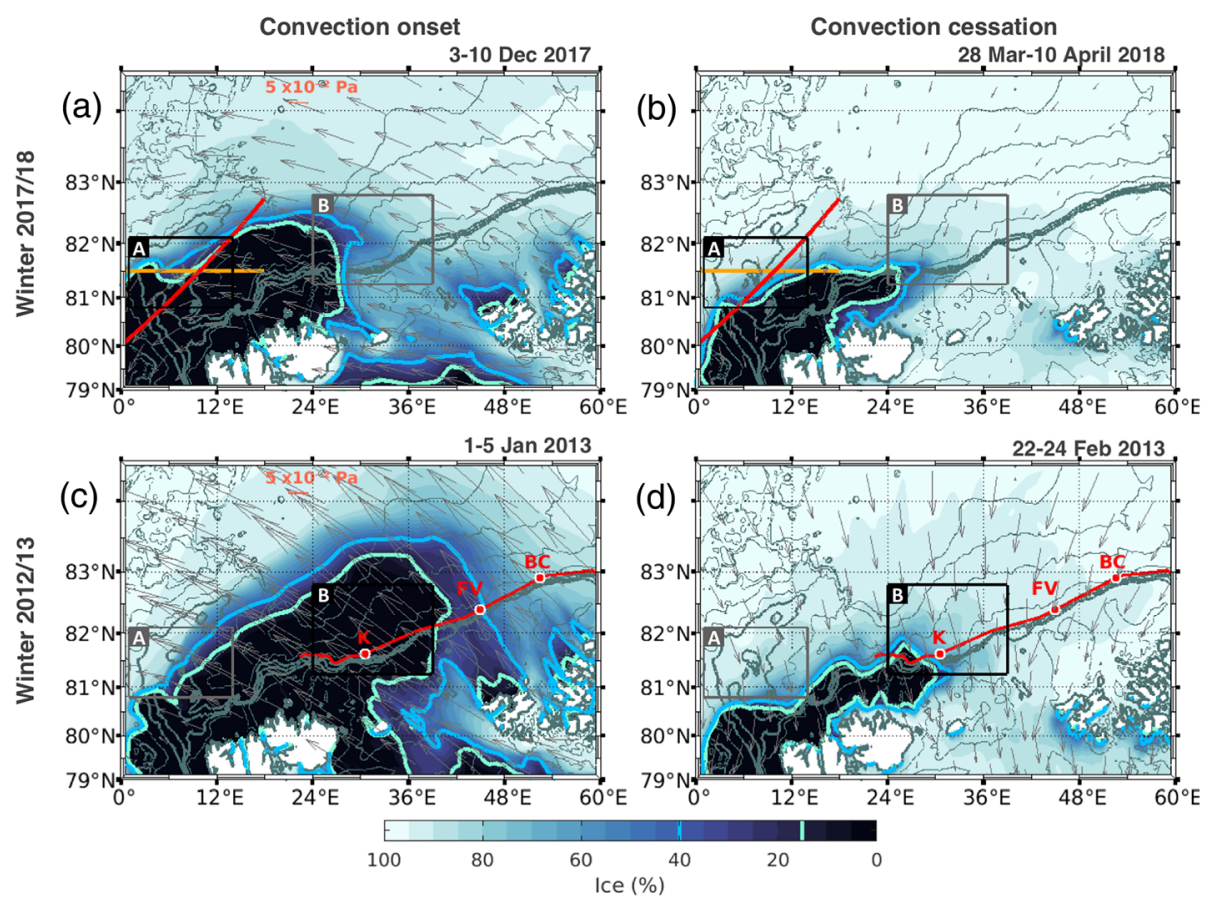

Figure 10. (a) Wind stress (gray arrows, pa; plotted every 15 grid cell) and sea-ice concentration (background color, \%) averaged during the onset and (b) cessation of deep convection in winter 2017/18. Green and cyan contours are respectively the 15 and $40 \%$ ice cover limit. The red and orange sections over the northern Yermak plateau (box a) are presented in Figure 11. (c) Same for the onset and (d) cessation of deep convection in winter 2012/13. The red section along the continental slope (box B) is presented in Figure 13. Boxes a and B are the same as in Figures 8 and 9.

$83^{\circ} \mathrm{N}$, the occurrence of storms inducing strong mixing, large negative heat fluxes (mean of $-230 \mathrm{~W} / \mathrm{m}^{2}$ during 4 months), and wind conditions favorable to pushing the ice out of the area (Figures 9a-e, 10a, Supporting Information S1).

Deep mixed layers in excess of 300 m lasted for over 4 months. In mid-December they developed under widely ice-free conditions on the western part of Yermak Plateau and with AW temperatures above $3{ }^{\circ} \mathrm{C}$ extending from the surface down to $450 \mathrm{~m}$ at $81.5^{\circ} \mathrm{N}$ (Figure 11c). On December 22, MLDs were about $100 \mathrm{~m}$ in the Fram Strait part of the section $\left(0-2^{\circ} \mathrm{E}\right)$, reached $300 \mathrm{~m}$ in the core of the AW northward flow $\left(2-6^{\circ} \mathrm{E}\right), 170 \mathrm{~m}$ in the southward Yermak Pass Branch $\left(6-9^{\circ} \mathrm{E}\right), 200 \mathrm{~m}$ within a mesoscale structure detached from the slope over the Sofia Deep $\left(12-14^{\circ} \mathrm{E}\right)$ and $80 \mathrm{~m}$ in the westward flow above the offshore part of the Svalbard Continental Slope (SCS, $16-18^{\circ}$ E; Figure 11c). The corresponding T-S diagram showed that convection over Yermak Plateau (YP) and Sofia Deep (SD) could reach the $27.85 \sigma$-horizon at that time (low- ${ }^{2}$ points circled in black in Figure 12a).

Three months later, the northern part of YP was ice-covered with the ice edge at $10^{\circ} \mathrm{E}$ (Figure $11 \mathrm{~d}$ upper panel). Local deep convection ceased over the northern YP while it continued over SD and the continental slope which were still ice-free (Figure 11d). Convected waters over YP were found down to $500 \mathrm{~m}$ (reaching the YP sea-floor; Figure 11d) and had densities between 27.9 and $27.95 \mathrm{~kg} / \mathrm{m}^{3}$ over a reduced temperature and salinity range (CT: $2.0-2.8^{\circ} \mathrm{C}, \mathrm{SA}: 35.1-35.2 \mathrm{~g} / \mathrm{kg}$, red dots in Figure $\left.12 \mathrm{~b}\right)$. Mixed layers in the SD were denser $\left(>27.95 \mathrm{~kg} / \mathrm{m}^{3}\right.$, also down to $\left.500 \mathrm{~m}\right)$, with even more reduced temperature and salinity range (centered around $2{ }^{\circ} \mathrm{C}, 35.15 \mathrm{~g} / \mathrm{kg}$; blue dots, Figure 12b). Convecting waters over the Svalbard branch (down to $600 \mathrm{~m}$; SCS in Figure 11d) had characteristics slightly warmer and saltier than in the SD straddling isopycnal $27.95 \mathrm{~kg} / \mathrm{m}^{3}$ (centered around $2.4^{\circ} \mathrm{C}, 35.17 \mathrm{~g} / \mathrm{kg}$; green dots circled in black, Figure $12 \mathrm{~b}$ ).

At the same date (29 March 2018), a southwest-northeast section showed that convection was still active over the still ice-free southern part of YP (south of $81^{\circ} \mathrm{N}$ ), and had ceased over the northern SD as northerly winds imported sea-ice and meltwater (ice edge at $10^{\circ} \mathrm{E}$; Figure 10b, Supporting Information S1). Ventilated waters extended as far northward as $82.2^{\circ} \mathrm{N}-16^{\circ} \mathrm{E}$ (Figure 11e). At the north-east edge of the section, mixed layer 

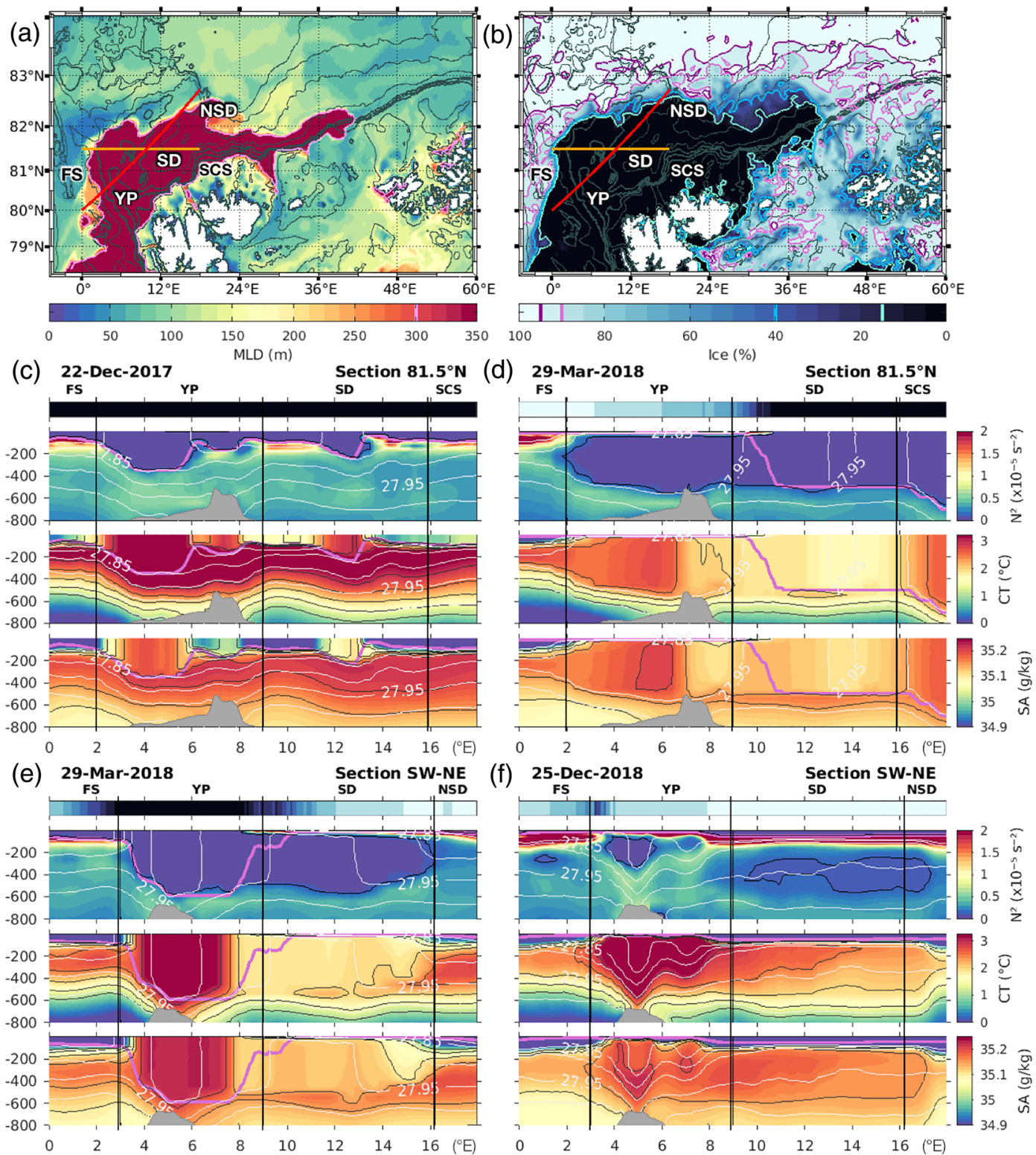

Figure 11. (a) Maximum MLD (in m) reached at each point in winter 2017-2018. (b) Associated Sea-ice coverage (\%) Contours are 15 (green), 40 (blue), 90 (pink) and 95\% (purple). (c)-(d) (top panel) snapshots of sea-ice coverage (\%), colorbar same as (b). (second panel) Brunt-Väisälä frequency $\left(\mathrm{N}^{2}, \mathrm{~s}^{-1}\right)$, (third panel) conservative temperature $\left(\mathrm{CT},{ }^{\circ} \mathrm{C}\right)$, and (lower panel) absolute salinity (SA, g/kg) on the $81.5^{\circ} \mathrm{N}$ zonal section (orange segment in a and b). (e)-(f) same on the SW-NE section (red line in a and b). X-axis is longitude (degrees), y-axis depth in $\mathrm{m}$. the thick pink line is the MLD. Black isolines are the $1 \times 10^{-6} \mathrm{~s}^{-1}$ threshold in $\mathrm{N}^{2}$, isotherms every $0.5^{\circ} \mathrm{C}$ from 1 to $3^{\circ} \mathrm{C}$, and isohalines every $0.05 \mathrm{~g} / \mathrm{kg}$ from 35 to $35.2 \mathrm{~g} / \mathrm{kg}$. White isolines are isopycnals from 27.8 to $28 \mathrm{~kg} / \mathrm{m}^{3}$ every $0.05 \mathrm{~kg} / \mathrm{m}^{3}$. Vertical black lines delineate the regions FS: Fram Strait; YP: Yermak plateau, SD: Sofia deep; NSD: Northern Sofia deep and SCS: Svalbard continental slope. IBCAO bathymetry along the sections is in gray filled areas.

depths never exceeded $100 \mathrm{~m}$ : the AW below was not ventilated that winter and remained warmer and saltier than $\mathrm{AW}$ in $\mathrm{SD}\left(2.7^{\circ} \mathrm{C}, 35.18 \mathrm{~g} / \mathrm{kg}\right.$, Figure 11e east of $16^{\circ} \mathrm{E}$, purple dots in Figure 12c). Comparisons between Figures 11d and 11e west of $7^{\circ} \mathrm{E}$ highlighted the intense cooling and freshening of the AW inflow along its northward progression on the westward part of $\mathrm{YP}\left(-1.5^{\circ} \mathrm{C}\right.$ and $-0.2 \mathrm{~g} / \mathrm{kg}$ over $80 \mathrm{~km}$ ). Indeed, low- $\mathrm{N}^{2} \mathrm{AW}$ undergoing strong modifications over the southern YP (red dots circled in black centered at $27.91 \mathrm{~kg} / \mathrm{m}^{3}, 35.22 \mathrm{~g} / \mathrm{kg}$ and $3.2^{\circ} \mathrm{C}$, Figure $12 \mathrm{c}$ ) were much warmer, saltier and lighter 

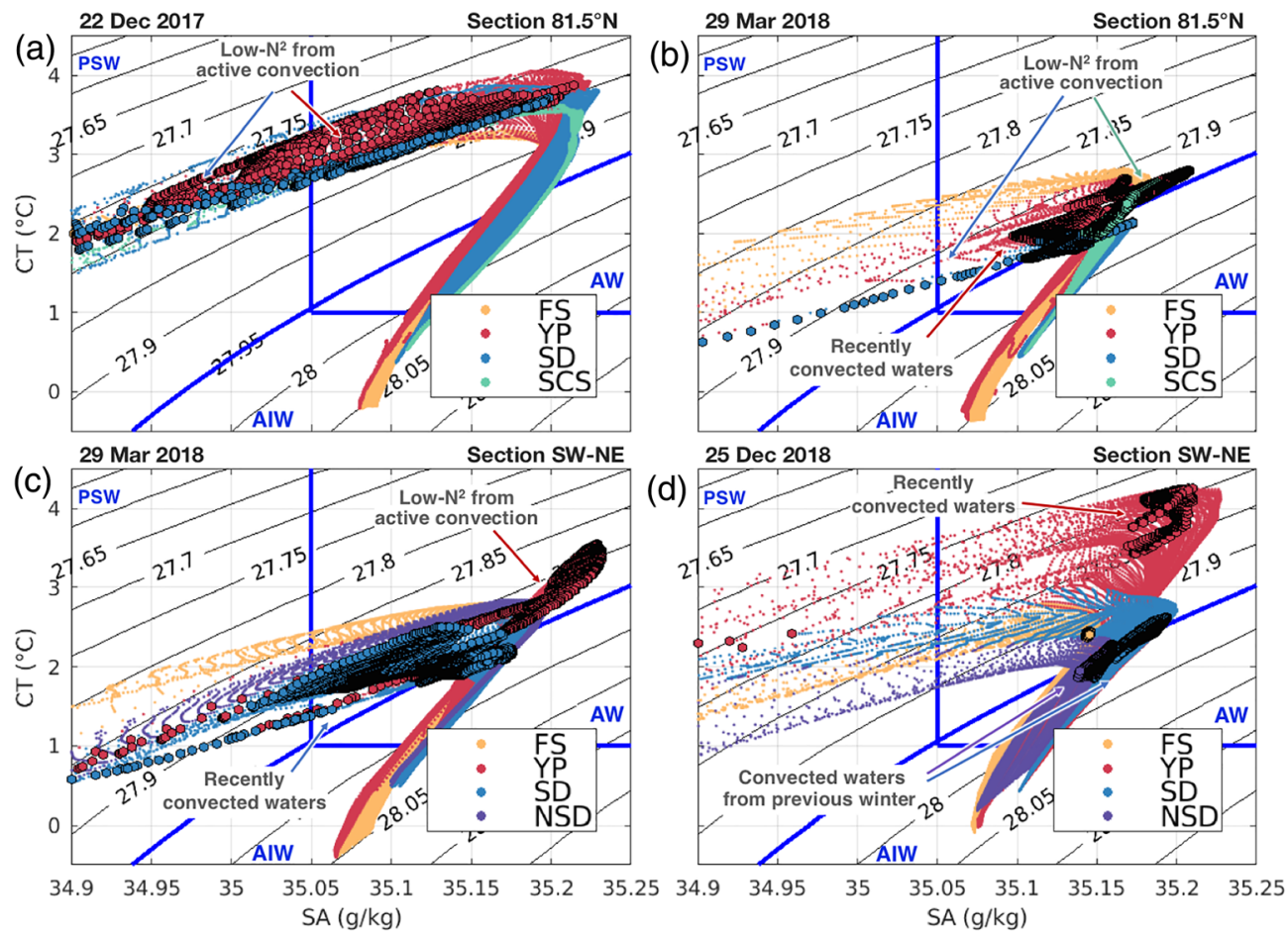

Figure 12. CT-SA diagrams of the sections (c) to (e) shown in Figure 11, upper $800 \mathrm{~m}$ of the water column, focused on the AW properties. (a) 22 December 2017 (corresponding to Figure 11c), (b) 29 march 2018 (corresponding to Figure 11d) at the zonal section (orange, Figure 11a). Profiles in the Fram Strait (FS) are in yellow, over Yermak plateau (YP) in red, Sofia deep (SD) in blue, and over the Svalbard continental slope (SCS) in green. (c) 29 march 2018 (corresponding to Figure 11e), (d) 25 December 2018 (corresponding to Figure 11f) at the SW-NE section (red, Figure 11a). Profiles in the Fram Strait (FS) are in yellow, over Yermak plateau (YP) in red, Sofia deep (SD) in blue, and northern Sofia deep (NSD) in purple. Water parcels with low- $\mathrm{N}^{2}\left(<10^{-6}\right)$ are circled in black. Isopycnal $27.95 \mathrm{~kg} \mathrm{~m}^{-3}$ is highlighted in blue. AW: Atlantic water; AIW: Arctic intermediate water; PSW: Polar surface water.

than low- $\mathrm{N}^{2}$ AW encountered further north (red dots circled in black above the $27.95 \mathrm{~kg} / \mathrm{m}^{3}$ isopycnal in Figure 12b).

Deep convection stopped soon afterward and, by mid-April the $81.5^{\circ} \mathrm{N}$ section was fully ice-covered and the upper water column stratified all over (not shown). Convection over the AW inflow above YP impacted a wide range of water T-S characteristics down to isopycnal $27.95 \mathrm{~kg} / \mathrm{m}^{3}\left(\mathrm{CT} \sim 2.1-3.4{ }^{\circ} \mathrm{C}\right.$, SA $~ 35.09-35.22 \mathrm{~g} / \mathrm{kg}$; isopycnal range $27.90-27.95 \mathrm{~kg} / \mathrm{m}^{3}$ ) and reached an even deeper horizon of $27.97 \mathrm{~kg} / \mathrm{m}^{3}$ over the continental slope off Svalbard $\left(\mathrm{CT} \sim 1.8-2.3{ }^{\circ} \mathrm{C}\right.$; $\mathrm{SA} \sim 35.13-35.17 \mathrm{~g} / \mathrm{kg}$; narrow isopycnal range $\left.27.95-27.97 \mathrm{~kg} / \mathrm{m}^{3}\right)$ and the $\mathrm{SD}\left(\mathrm{CT} \sim 1.7-2.3{ }^{\circ} \mathrm{C}, \mathrm{SA} \sim 35.1-35.17 \mathrm{~g} / \mathrm{kg}\right.$; large isopycnal range 27.91-27.97 kg/m ${ }^{3}$ ) (Figures 12b, 12c). Over the Fram Strait part of the sections, conditions remained mostly ice-covered and no deep convection developed.

We attempted to follow the low- $\mathrm{N}^{2}$ waters (Supporting Information S1). Part of those that formed over YP were advected into SD where they joined the dense SD-ventilated waters. At the beginning of the following winter (on December 25, Figure 11f), low- $\mathrm{N}^{2}$ waters formed during the previous winter ventilation were still present in $\mathrm{SD}$ on the $27.95 \sigma$-horizon $\left(\mathrm{CT} \sim 1.8-2.7^{\circ} \mathrm{C}\right.$, blue and purple dots circled in black in Figure 12d), while convection had started again on the western side of YP (recently convected waters with $\mathrm{CT} \sim 3.5-4.3^{\circ} \mathrm{C}$, red dots circled in black in Figure $12 \mathrm{~d}$ ).

\subsection{Low- $\mathrm{N}^{2}$ Waters Along the Continental Slope in Winter 2012/13}

The extreme winter 2012/13 along the slope was documented with the A-TWAIN mooring array. Pérez-Hernández et al. (2019) examined deep mixed layer formation and subsequent AW characteristics evolution, while Renner et al. (2018) quantified AW heat loss over the slope. PSY4 was shown to accurately reproduce the A-TWAIN observations (section 3.4). 

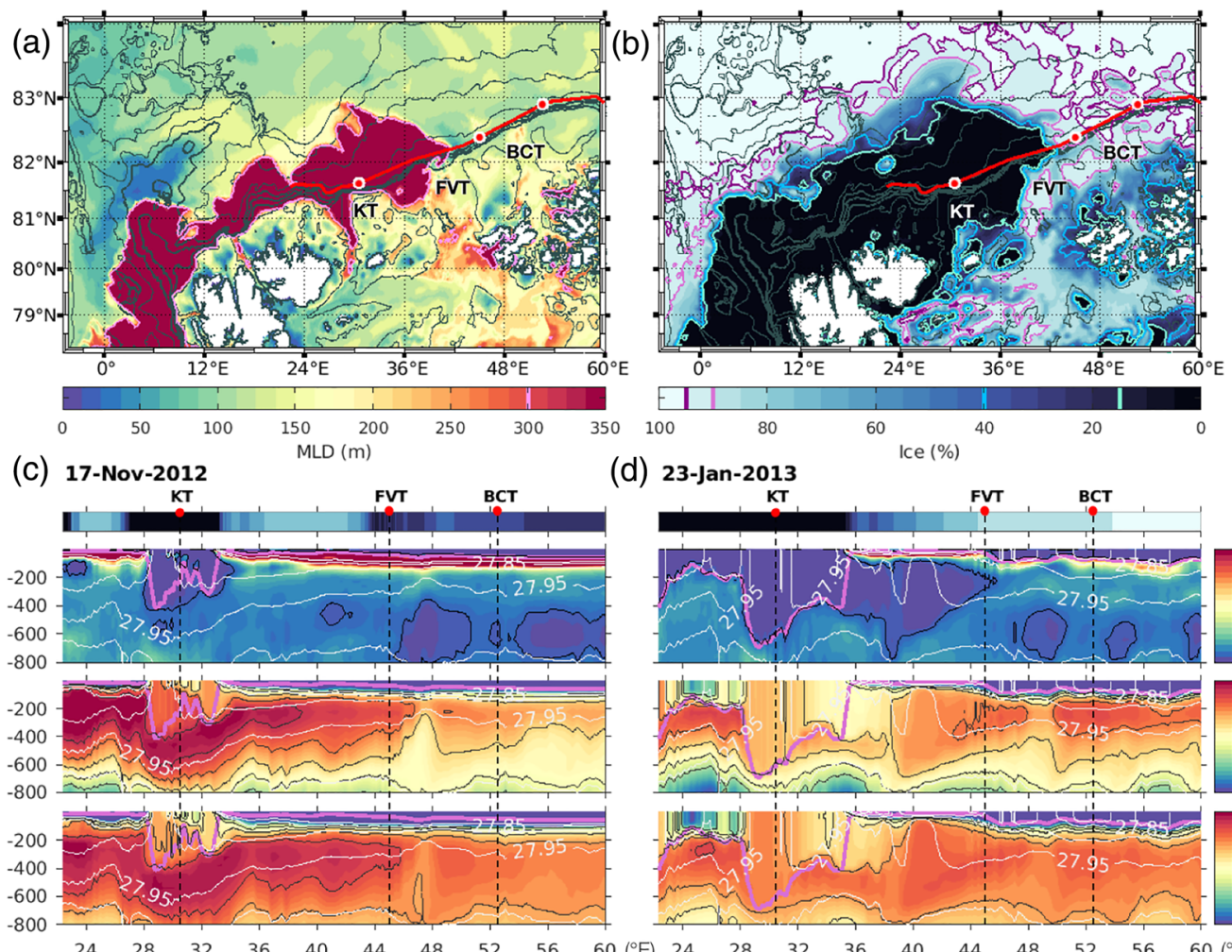

(d) 23-Jan-2013
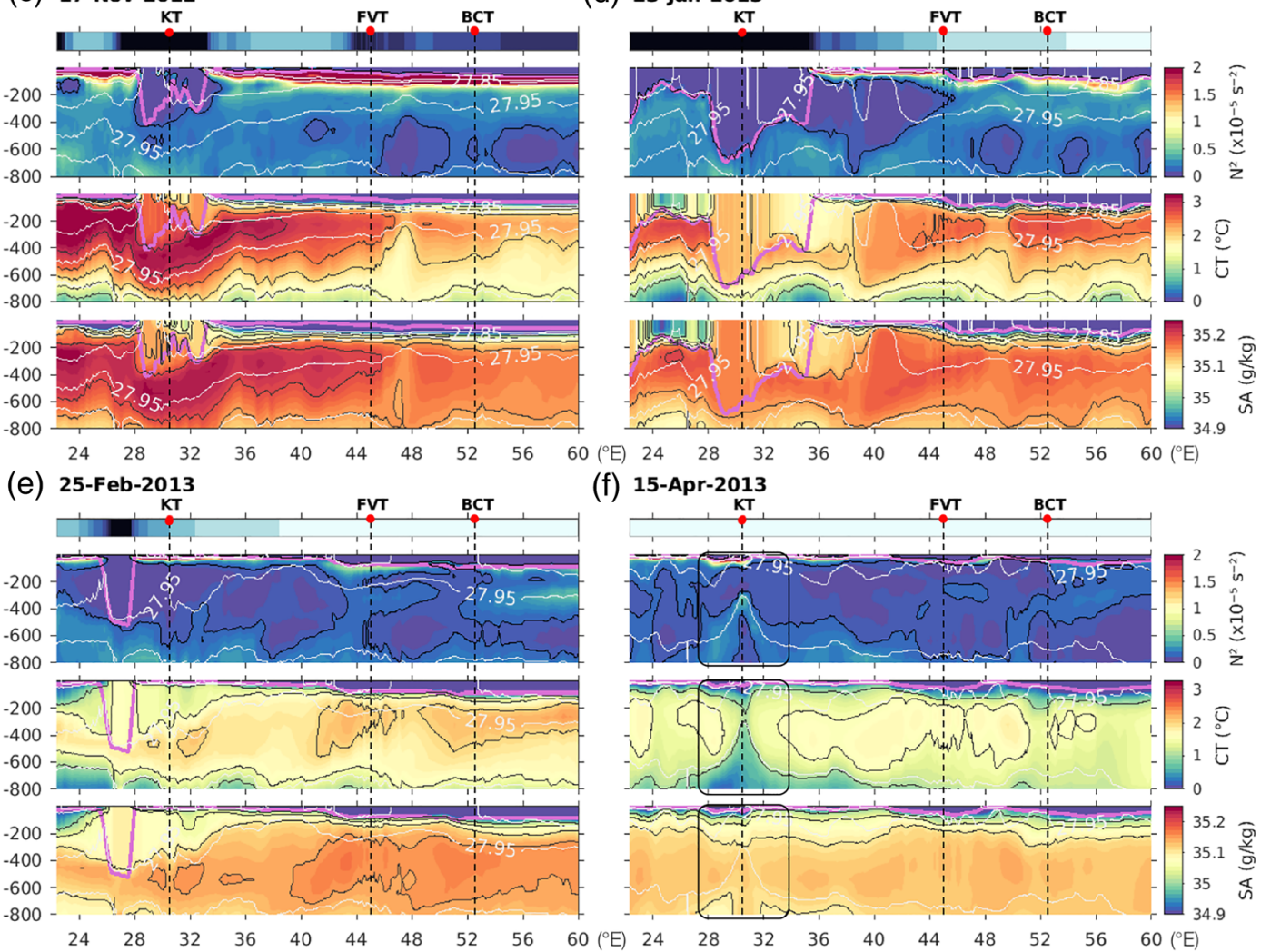

(f) 15-Apr-2013

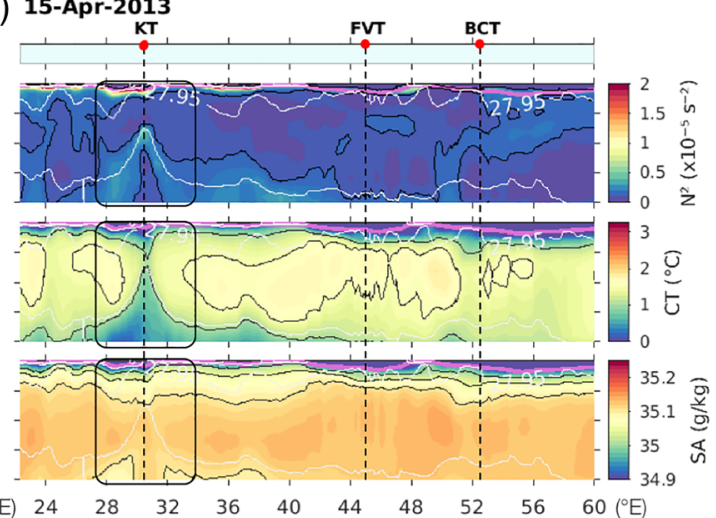

Figure 13. (a) Maximum MLD (in m) reached at each point in 2012-2013 winter. (b) Associated Sea-ice cover (\%) Highlighted contours are 15, 40, 90, and 95\% in green, blue, pink, and purple respectively. (c)-(f) (top panel) snapshots of sea-ice coverage (\%), colorbar same as (b). (second panel) Brunt-Väisälä frequency $\left(\mathrm{N}^{2}, \mathrm{~s}^{-1}\right)$, (third panel) conservative temperature $\left(\mathrm{CT},{ }^{\circ} \mathrm{C}\right)$, and (lower panel) absolute salinity $(\mathrm{SA}, \mathrm{g} / \mathrm{kg}$ ) at the along-slope section shown on (b) (red line along the 1,000 $\mathrm{m}$ isobath). The thick pink line is the MLD at each date. Vertical dashed lines indicate the eastern flank location of the three troughs north-east of Svalbard; KT: Kvitøya trough, FVT: Franz-Victoria trough, BCT: British Channel trough. The A-TWAIN array (mooring WHOI-1) was located at $31^{\circ} \mathrm{E}$ just east of Kvitøya trough. Black isolines are the $1 \times 10^{-6} \mathrm{~s}^{-1}$ threshold in $\mathrm{N}^{2}$, isothermals from 1 to $3^{\circ} \mathrm{C}$ every $0.5^{\circ} \mathrm{C}$, and isohalines from 35 to $35.2 \mathrm{~g} / \mathrm{kg}$ every $0.05 \mathrm{~g} / \mathrm{kg}$. White isolines are isopycnals, from 27.8 to $28 \mathrm{~kg} / \mathrm{m}^{3}$ every $0.05 \mathrm{~kg} / \mathrm{m}^{3}$. Black boxes on (f) indicate the dense outflow described in section 5.2.

In 2012/13, modeled MLDs exceeding $200 \mathrm{~m}$ were not confined to the continental slope (isobaths 200$2000 \mathrm{~m}$ ), they extended as far as $82.7^{\circ} \mathrm{N}$ above isobaths 3,400-3,800 $\mathrm{m}$ (offshore) (Figure 13a). These deep MLDs formed over open water areas as strong northwestward winds exported the ice away (Figures 10c, 13b, Supporting Information S2). The loose sea-ice cover (40 to 95\% coverage) in the rest of the basin led to maximum MLDs above $100 \mathrm{~m}$. In contrast, the minimum MLDs, less than $50 \mathrm{~m}$ seen on the north of Yermak Plateau (in blue in Figure 13a), corresponded to a steep sea-ice concentration gradient associated with active ice melt creating a fresh layer at the surface (Figure 13b). 

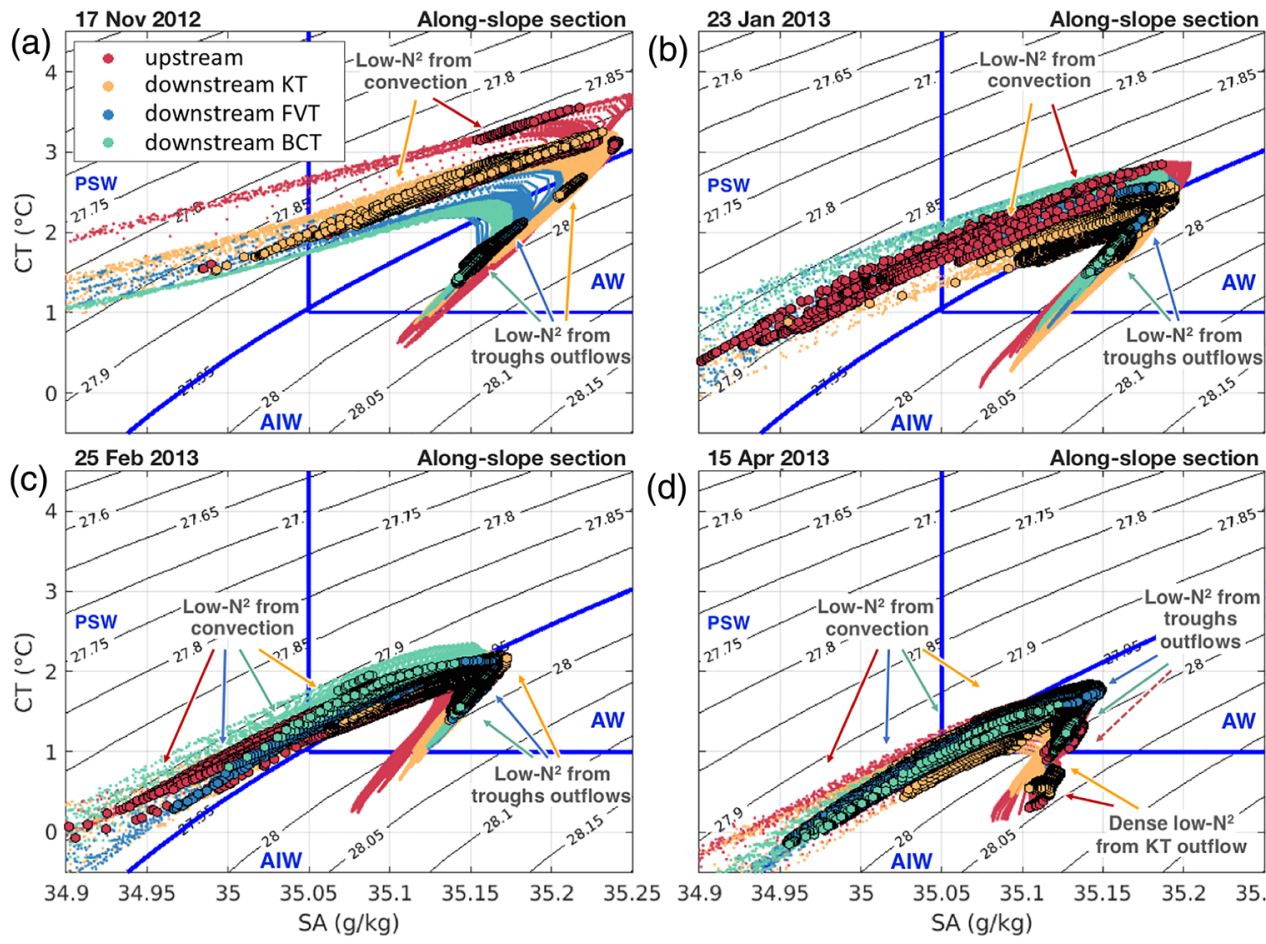

(d)

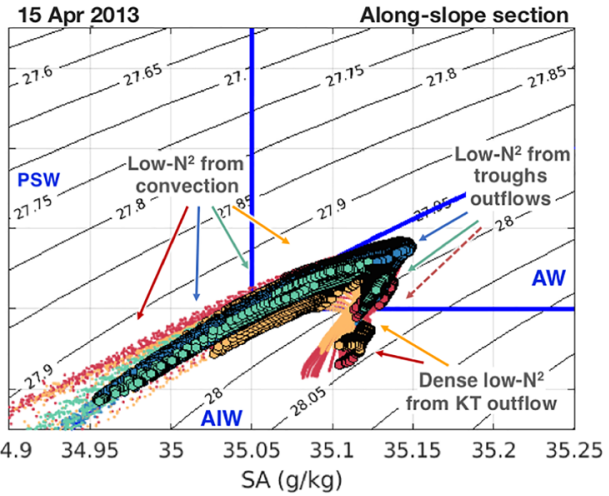

Figure 14. CT-SA diagrams of the sections (c) to (e) shown in Figure 13, upper $800 \mathrm{~m}$ of the water column, focused on the AW properties. Every other profile is plotted for sake of clarity. (a) 17 November 2013 (corresponding to Figure 13c), (b) 23 January 2013 (corresponding to Figure 13d), (c) 25 February 2013 (corresponding to Figure 13e) and (d) 15 April 2013 (corresponding to Figure 13f) at the along-slope section (red, Figure 13a). Profiles upstream of Kvitøya trough are in red. Profiles between Kvitøya and Franz-Victoria troughs are in yellow (downstream KT), between Franz-Victoria and British Channel troughs in blue (downstream FVT), and downstream of British Channel trough in green (downstream BCT). Water parcels with low- $\mathrm{N}^{2}\left(<10^{-6} \mathrm{~s}^{-1}\right)$ are circled in black. Isopycnal 27.95 is highlighted in blue. AW: Atlantic water; AIW: Arctic intermediate water; PSW: Polar surface water.

We closely monitored the evolution of ice, $\mathrm{N}^{2}$, temperature and salinity on a section along the 1,000 $\mathrm{m}$ isobath (red line on Figure 13b). Four snapshots illustrated the beginning of winter convection (17 November 2012), a time of particularly deep convection (23 January 2013), continuous freshening and cooling throughout the upper $800 \mathrm{~m}$ (25 February) and restratification in early spring (15 April). Regions with isopycnals outcropping to the surface corresponded to ice-free regions with active convection taking place: isopycnal $27.90 \mathrm{~kg} / \mathrm{m}^{3}$ outcropped between 28 and $32^{\circ} \mathrm{E}$ on November 17 (Figure 13c); isopycnal $27.95 \mathrm{~kg} / \mathrm{m}^{3}$ on January 23 (Figure 13d). On November 17, the AW core layer was warm and salty $\left(>3{ }^{\circ} \mathrm{C}\right.$, $>35.2 \mathrm{~g} / \mathrm{kg}$ ) and the $27.95 \mathrm{~kg} / \mathrm{m}^{3}$ isopycnal was depressed down to $600 \mathrm{~m}$ while active convective mixing took place down to $400 \mathrm{~m}$. On January 23, when the A-TWAIN mooring WHOI-1 (point KT on Figure 13d) first registered deep MLD (>400 $\mathrm{m}$ deep), the model showed convection down to $600 \mathrm{~m}$ supporting the extreme MLDs observed in-situ (Pérez-Hernández et al., 2019). AW was considerably cooled and freshened through convective mixing in the ice-free areas (Figures 13c, 13d). Later, northerly winds imported sea-ice in the area (Figure 10d; Supporting Information S2), restratification took place and, below a thin cold and fresh layer, the water column remained with a small $\mathrm{N}^{2}$, low temperature and salinity (below $2{ }^{\circ} \mathrm{C}$ and $35.15 \mathrm{~g} / \mathrm{kg}$ ) (Figure 13e). CT-SA diagrams corresponding to the sections in Figure 13 illustrated further the spectacular contraction in AW properties (cooling, freshening, densifying) through winter and the respective contributions from surface convection and from the troughs to low- $\mathrm{N}^{2}$ waters (Figure 14).

Plumes of low- $\mathrm{N}^{2}$ waters below the 27.95 isopycnal were often observed at depths throughout the year, for example in Figures 13c-f. As seen in section 3.3 and Figure 5, outflows of shelf-modified AW (SMAW) from troughs showed low- $\mathrm{N}^{2}$ values. The source of the low- $\mathrm{N}^{2}$ plumes were outflows from the following troughs: Kvitøya (KT), Franz-Victoria (FVT), and British-Channel troughs (BCT) (Figures 1, 13c-f). At the beginning of winter, the lighter low- $\mathrm{N}^{2}$ waters from surface convection were clearly separated from the denser low- $\mathrm{N}^{2}$ waters transported from trough outflows (Figure 14a), whereas later in winter there was a continuum in low- 

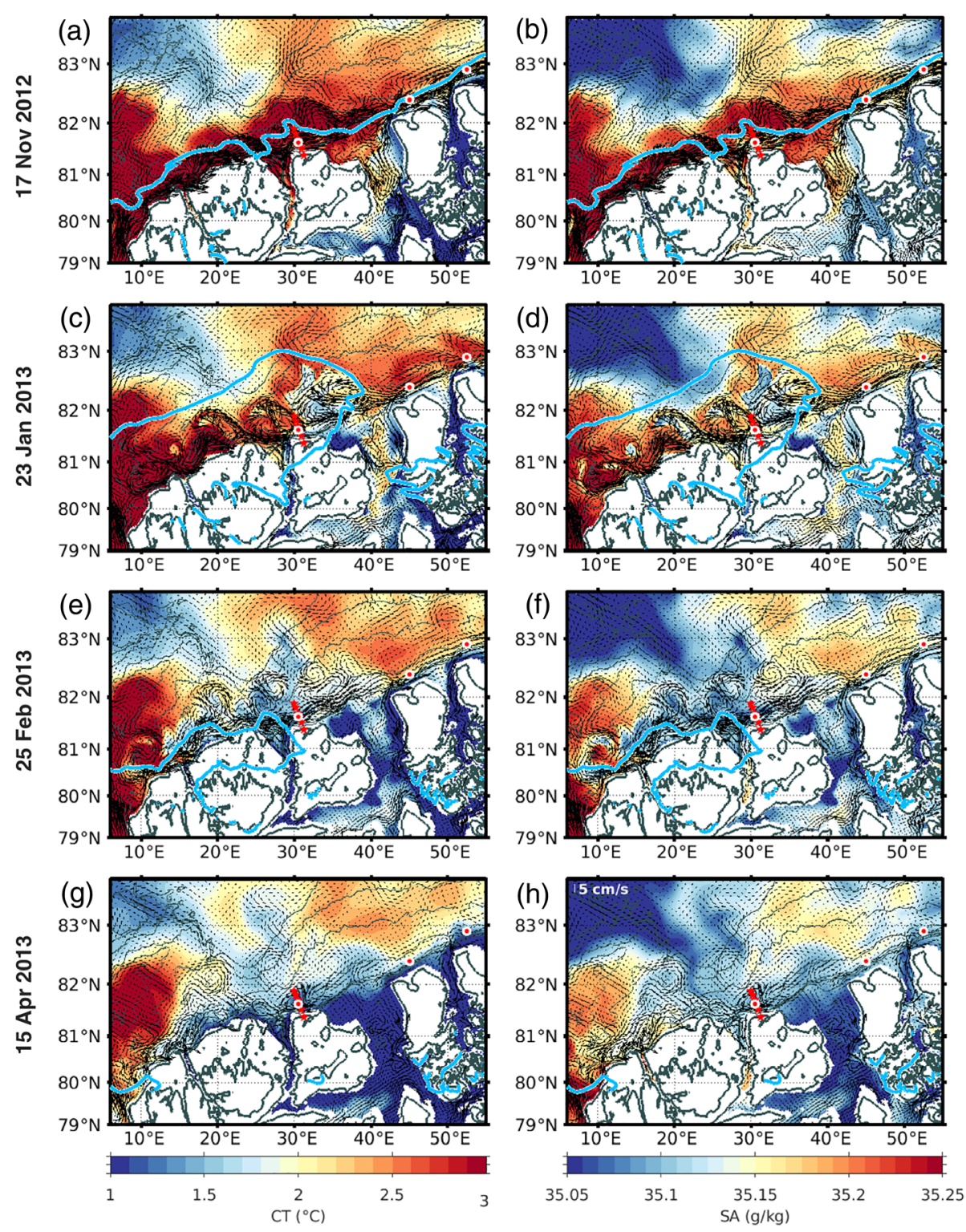

Figure 15. (a) Conservative temperature $\left(\mathrm{CT},{ }^{\circ} \mathrm{C}\right)$ and $(\mathrm{b})$ absolute salinity $(\mathrm{SA}, \mathrm{g} / \mathrm{kg})$ fields at $265 \mathrm{~m}$ on 17 November 2012. The thick blue contour is the sea-ice edge (40\% ice cover) on that date. Arrows are current velocities at $265 \mathrm{~m}$. red dots at $30^{\circ} \mathrm{E}$ are A-TWAIN moorings, red dots circled in white correspond to points KT, FVT and BCT in Figure 13. (c)-(d) same on the 23 January 2013, (e)-(f) on 25 February 2013 and (g)-(h) on 15 April 2013.

$\mathrm{N}^{2}$ waters down to $28.0 \sigma$-horizon (Figures $14 \mathrm{~b}$ and c). The low- $\mathrm{N}^{2}$ waters from the troughs likely resulted from convection in the Barents Sea (e.g. Pfirman et al., 1994; Steele et al., 1995). Therefore, both local and distant convection in the Barents Sea contributed to AW modification along the slope.

On April 15, an apparent disruption of the AW layer at $31^{\circ} \mathrm{E}$ (Figure 7d, and point $\mathrm{KT}$ in Figure 13f) was also observed on A-TWAIN moorings at the same date (Renner et al., 2018; see section 3.4. and Figure 7c). The corresponding CT-SA diagram (Figure 14d) featured an exceptionally dense $\left(\sigma>28.02 \mathrm{~kg} / \mathrm{m}^{3}\right)$ low- $\mathrm{N}^{2}$ pattern. This unique event in the period 2012/13 is examined below.

\section{Aw Boundary Current Exchange With the Deep Nansen Basin and Barents Sea: Examples From Winter 2012/13}

Along the continental slope, exchange with the deep Nansen Basin and the Barents Sea contributed to modify AW characteristics. 


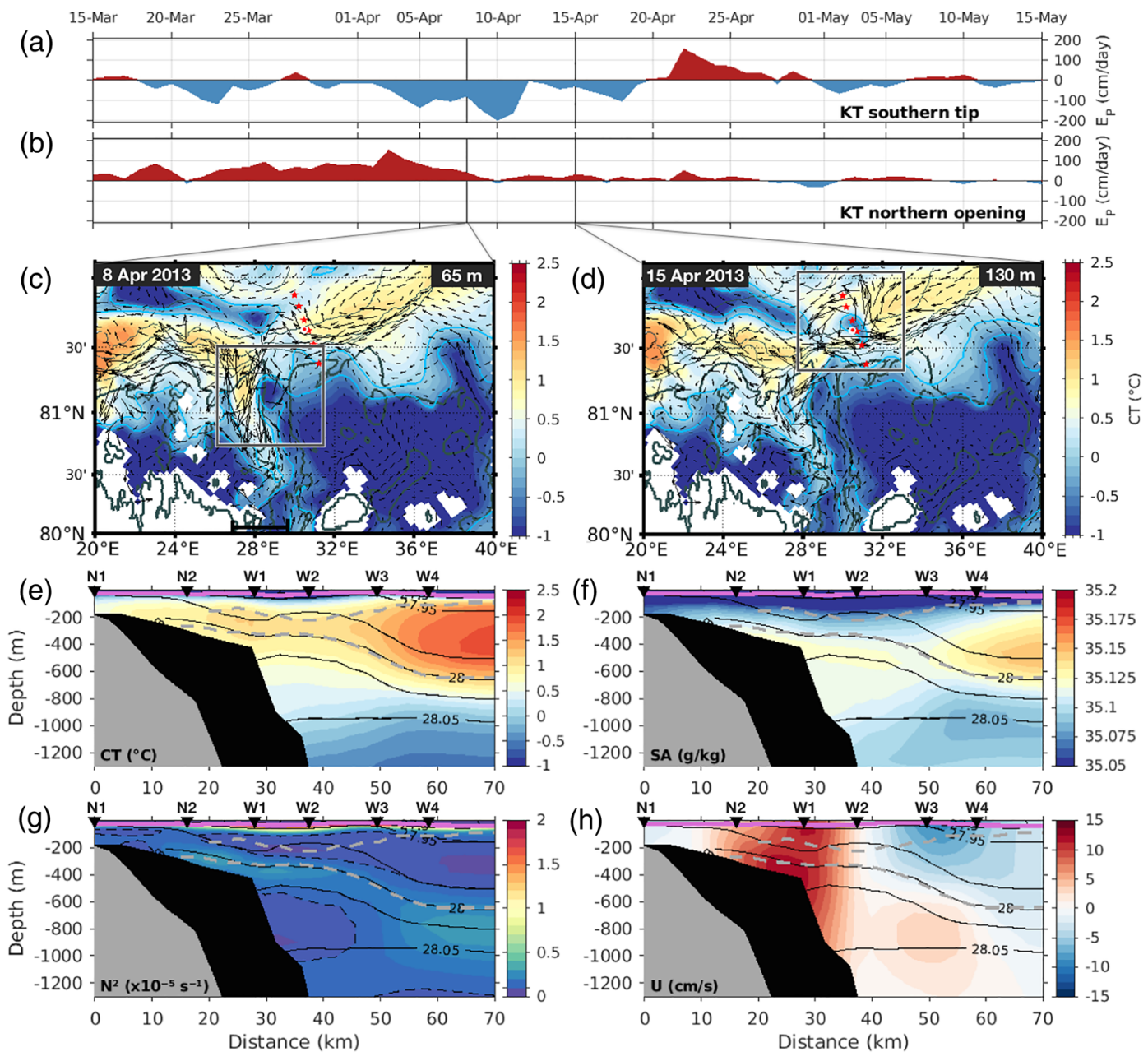

Figure 16. Time series of Ekman pumping (a) at the southern tip and (b) northern opening of Kvitøya trough (KT), between mid-march and mid-may 2013. Ekman pumping was computed from daily averaged wind stress components over $27-30^{\circ} \mathrm{E}, 79.6-80^{\circ} \mathrm{N}$, and $27-30^{\circ} \mathrm{E}, 81.4-81.7^{\circ} \mathrm{N}$ south and north of $\mathrm{KT}$ respectively. Vertical lines are dates shown in (c), (d). Conservative temperature $\left(\mathrm{CT},{ }^{\circ} \mathrm{C}\right.$ ) field (c) at $65 \mathrm{~m}$ on 8 April 2013, when a cold-core cyclonic eddy formed within Kvitøya trough and (d) at $130 \mathrm{~m}$ on 15 April 2013 when the eddy was passing the A-TWAIN array. Arrows are the current velocity $(\mathrm{cm} / \mathrm{s})$ at that depth. Blue contours are isotherms -0.5 and $0{ }^{\circ} \mathrm{C}$. red dots are A-TWAIN moorings, red dots correspond to point KT in Figure 13. Gray boxes indicate the location of the eddy. IBCAO bathymetry is in gray contours. (e) Conservative temperature $\left(\mathrm{CT},{ }^{\circ} \mathrm{C}\right),(\mathrm{f})$ absolute salinity $(\mathrm{SA}, \mathrm{g} / \mathrm{kg}),(\mathrm{g})$ brunt-Väisälä frequency $\left(\mathrm{N}^{2}, \mathrm{~s}^{-1}\right)$ and $(\mathrm{h})$ cross-section velocity (U, cm/s) colocated along the A-TWAIN mooring array in the model fields on 15 April 2013 (to be compared with the mean conditions on Figures 6b-c). On (e)-(h), the MLD is the thick pink line. Isopycnals (black contours) are plotted from 27.9 to $28.05 \mathrm{~kg} / \mathrm{m}^{3}$ every $0.025 \mathrm{~kg} / \mathrm{m}^{3}$. Dashed black lines on $(\mathrm{g})$ are contours such as $\mathrm{N}^{2}<10^{-6} \mathrm{~s}^{-1}$. Dashed gray lines are the AW layer boundaries. IBCAO bathymetry is in gray, model bathymetry in black.

\subsection{Overview of the Circulation in the Core of the AW}

To complement the along-slope sections shown in Figure 13, we produced mapped-snapshots of temperature, salinity, and horizontal velocity fields at $265 \mathrm{~m}$ (in the core of the AW layer) on the same dates (Figure 15). They illustrated the wealth of the mesoscale field along the slope, the flow in the troughs, and the cooling and freshening of AW.

The offshore area showed an interesting persistent large-scale pattern all winter round with colder and fresher modified AW from the interior intruding between warm and salty AW on the Yermak Plateau and an offshore less warm plume at $30^{\circ} \mathrm{E}$ (Figure 15). The energetic winter AW boundary current, with velocities often exceeding $15 \mathrm{~cm} / \mathrm{s}$, was unstable and developed an intense mesoscale field with meanders evolving into energetic eddy dipoles (Figures 15a, b). Eddies seemed to escape offshore along two preferred paths: a 

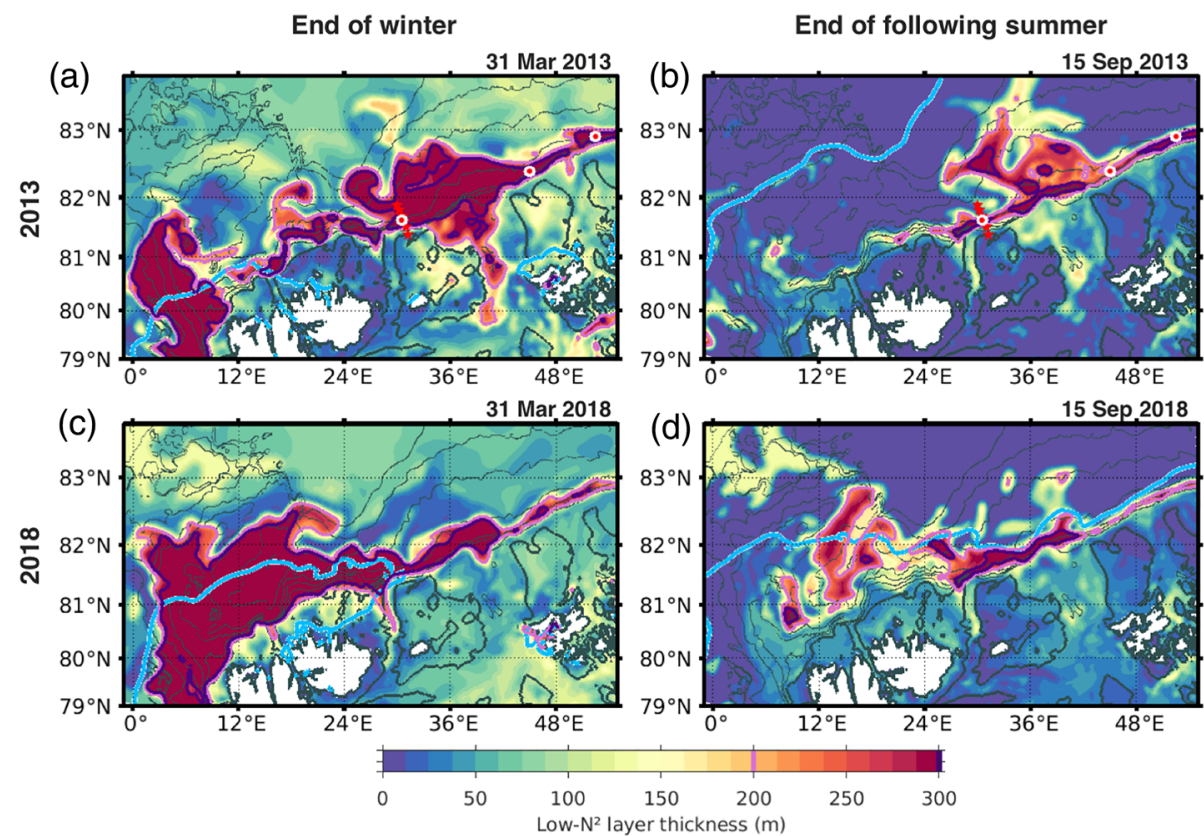

Figure 17. (a) Thickness of layers of low- $\mathrm{N}^{2}\left(<10^{-6} \mathrm{~s}^{-1}\right)$ in the upper $800 \mathrm{~m}$ of the ocean, at the end of winter 2012-2013 on 31 march 2013. (b) Same at the end of the following summer, on 15 September 2013. Areas where low- $\mathrm{N}^{2}$ layers exceeded $200 \mathrm{~m}(300 \mathrm{~m})$ at that date are delineated in pink (purple) contours. The thick blue contour is the sea-ice edge ( $40 \%$ ice cover) at that date. Red stars at $30^{\circ} \mathrm{E}$ are A-TWAIN moorings, red dots correspond to points KT, FVT and BCT in Figure 13. (c)-(d) same for winter 2017-2018.

northward path at $30^{\circ} \mathrm{E}$ (Figures $15 \mathrm{c}$ to f) and a more northeastward path parallel to the continental slope east of $40^{\circ} \mathrm{E}$ (Figures 15c, d). In January and February some eddies trapped colder and fresher water from the slope and carried it offshore (Figures 15c-f). At the end of winter, the AW boundary current was significantly weaker $(8 \mathrm{~cm} / \mathrm{s})$ with lower temperatures $\left(\mathrm{CT}<2{ }^{\circ} \mathrm{C}\right)$ in agreement with the seasonal cycle (e.g., Beszczynska-Möller et al., 2012).

Trough outflows, which often showed velocities on the order of those of the boundary current, contributed to modifying AW on the slope. The model trough outflows, identified with low $\mathrm{N}^{2}$ values, consisted of plumes of variable size: 100 to $400 \mathrm{~m}$ thick and 10 to $100 \mathrm{~km}$ wide (Figures $13 \mathrm{c}-13 \mathrm{f}, 16 \mathrm{~g}$ ). The water in the troughs continuously cooled and freshened throughout winter (at $265 \mathrm{~m} \mathrm{CT}<0.5{ }^{\circ} \mathrm{C}, \mathrm{SA}<35.05 \mathrm{~g} / \mathrm{kg}$ at the end of winter in all troughs; Figure 15). Once sea-ice was back and local convection stopped, cooling and freshening of the boundary current continued because of trough outflows (Figures 15e, f). As a result, in April 2013 the AW boundary current was the coldest and freshest at the exit of the troughs (Figures 15g, h).

\subsection{Disruption of the AW Layer on the 15 April 2013}

We analyzed the conditions that led to the disruption of the AW layer observed on 15 April 2013 (Figures 7, 12f) that stood out in the A-TWAIN time series (Pérez-Hernández et al., 2019; Renner et al., 2018). Two simultaneous features from Kvitøya trough were concurrently involved: a cyclone in the upper $300 \mathrm{~m}$ and below, a low- $\mathrm{N}^{2}$ plume with density in the range of intermediate water.

In early-April, wind stress curl conditions (very negative over Kvitøya trough and positive over the slope; Figures 16a, b) favored the outflow of a cyclonic fresh, cold-core, eddy (CT $\sim-0.5{ }^{\circ} \mathrm{C}, \mathrm{SA} \sim 35 \mathrm{~g} / \mathrm{kg}$, low$\mathrm{N}^{2}$, core radius of about $20 \mathrm{~km}$ ) from the trough where it developed (i.e. April 7 snapshot in Figure 16c). The cold-core eddy crossed the mooring array location on April 15 (Figure 16d, core at an offshore distance of $\sim 40 \mathrm{~km}$ in Figures 16e-h) and was observed in the upper $300 \mathrm{~m}$ at the same date in the mooring line (Renner et al., 2018). The modeled eddy tangential velocities reached $10 \mathrm{~cm} / \mathrm{s}$ in the upper $70 \mathrm{~m}$ on April 15 at the mooring site (Figures 16d, h). The eddy was then advected offshore north-eastward while losing its temperature signature and its spinning motion and could be followed until May 15 when it reached 
$34^{\circ} \mathrm{E}, 82^{\circ} \mathrm{N}$. Several such cold-core upper layer eddies can be identified in the A-TWAIN records (for example over 10 such eddies at NPI-2, Figure 7c).

In the model, the large uprising of isopycnals observed around mid-April $\left(28.00 \mathrm{~kg} / \mathrm{m}^{3} \sigma\right.$-horizon rose from 600 to $300 \mathrm{~m}$-depth between 29 and $31^{\circ} \mathrm{E}$, Figure 13f) was associated with a homogeneous dense plume of water $\left(\mathrm{CT} \sim 0{ }^{\circ} \mathrm{C}, \mathrm{SA} \sim 35.125 \mathrm{~g} / \mathrm{kg}, \sigma>28 \mathrm{~kg} / \mathrm{m}^{3}\right.$, Figures 16e-h) cascading from Kvitøya trough. The low- $\mathrm{N}^{2}$ plume settled within the upper-density range of Arctic Intermediate Water (AIW) in the depth range 500 to $1,000 \mathrm{~m}$ (Figures 16e-h) and was advected northeastward. The plume uplifted the upper part of intermediate waters (larger $\mathrm{N}^{2}$ values between 300 and $500 \mathrm{~m}$ in Figure 16g). Comparisons to the mean conditions (Figures 6b, c) highlighted the extreme disruption of the AW layer over the slope.

These April 15 conditions are reminiscent of observations by Schauer et al. (1997) along the slope in the Western Nansen Basin. They described the two different types of northern Barents Sea water found on the slope in summer 1993: an upper patch intruding in the core of AW and a lower patch at about $500 \mathrm{~m}$ depth, resulting from a dense bottom water plume from troughs encroaching the intermediate waters. Schauer et al. (1997) suggested intermittent draining of cold dense water from the shelf through the troughs. Our hypothesis is that this extremely dense water $\left(\sigma>28.05 \mathrm{~kg} / \mathrm{m}^{3}\right)$ was conditioned in the Barents Sea during winter and is seen outflowing from Kvitøya Trough into Nansen Basin following the appropriate wind conditions mentioned at the beginning of the section. Such an uplift of isopycnals was an exceptional event along the slope in winter 2012/13 and certainly influenced the mesoscale dynamics on the slope (Figure 16b). The remarkable concordance in the timing of this uplift in the observations and in the model suggested that the event was deterministically wind-driven (Figures 16a, b). However, an investigation of the dynamical processes at stake is beyond the scope of the present work.

\section{Summary and Discussion}

The evaluation of the Mercator Ocean operational physical system (PSY4), using nearly 1,500 independent temperature-salinity profiles and five years of mooring data (T, S, and currents) in the West-Spitsbergen Current, highlighted its performance in representing realistic Atlantic Water (AW) inflow and hydrographic properties, in spite of its inherent limitations.

Indeed, the model resolution is not fully eddy-resolving in the Western Nansen Basin (i.e. grid size of $4 \mathrm{~km}$, and Rossby deformation radius of $\sim 10 \mathrm{~km}$; Crews et al., 2018), it lacks tides which are important on the Yermak Plateau (Koenig, Provost, Sennéchael, et al., 2017; Padman et al., 1992) and on the shelf (Renner et al., 2018), and its bathymetry could be improved (Figure A1).

Winter mixed layers observations are rather scarce in the Western Nansen Basin. The PSY4 system agreed with the few observations available in the area, such as the 2012/13 A-TWAIN mooring data over the continental slope (Pérez-Hernández et al., 2019) and IAOOS buoys during N-ICE 2015 (Koenig, Provost, Villacieros-Robineau, et al., 2017; Meyer et al., 2017). In particular, favorable comparisons with A-TWAIN mooring time series of deep winter mixed layers and changes in AW over winter led us to examine winter conditions in the WNB over the 2007-2020 period. The model helped to describe the interannual variations of winter mixed layers and documented several processes at stake in modifying AW beyond winter convection: shelf-slope exchange via troughs, lateral exchange through vigorous eddies, and occasional uplift of deep waters.

We identified winters during which extreme deep mixed layers developed in areas that used to be ice-covered, that one could call "Marginal Convection Zones": 2017/18 over the northern part of Yermak Plateau and 2012/13 on the continental slope northeast of Svalbard. In contrast with the neighboring Whalers' Bay where deep winter mixed layers are recurrent, "Marginal Convection Zones” only occasionally undergo deep winter convection.

Winter surface convection dramatically altered AW properties over Yermak Plateau and Sofia Deep in winter 2017/18. Over the continental slope, trough outflows were an additional important process in further AW modification, as documented for winter 2012/13. Recently modified AW was identified through low- $\mathrm{N}^{2}$ values (i.e. homogeneous layers). At the end of winter, the layers of low- $\mathrm{N}^{2}$ were around $100 \mathrm{~m}$-thick (vertical extent $\mathrm{E} \sim 100 \mathrm{~m}$ ) in the Western Nansen Basin (which corresponded to the winter mixed layer) except in areas where deep convection occurred (Figures 17a, 17c). The thick ( $\mathrm{E}>300 \mathrm{~m}$ ) low- $\mathrm{N}^{2}$ layers were 
laterally bordered with thin low- $\mathrm{N}^{2}$ layers $(\mathrm{E}<20 \mathrm{~m})$ where active ice melt likely prevented the development of convection. The spatial distribution of thick low $-\mathrm{N}^{2}$ AW layers $(\mathrm{E}>300 \mathrm{~m})$ were different at the end of the two extreme winters (Figures 17a, 17c). In March 2013, thick low- $\mathrm{N}^{2}$ layers between 24 and $44^{\circ} \mathrm{E}$ extended from the slope offshore to the north of $82.5^{\circ} \mathrm{N}$ (Figure 17a). In contrast, in March 2018 they widely covered Yermak Plateau and Sofia Deep (as far as $82^{\circ} \mathrm{N}$ and from 4 to $18^{\circ} \mathrm{E}$ ) and were reduced over the slope (Figure 17c). We followed the evolution of the thick homogeneous layers in time (Supporting Information $\mathrm{S} 1$ and $\mathrm{S} 2$ ). At the end of the following summer, they were eroded. The remaining thick low- $\mathrm{N}^{2}$ layers were mostly found east of $30^{\circ} \mathrm{E}$ in September 2013 (Figure 17b) and in the Sofia Deep in September 2018 (Figure 17d). The volume of the low- $\mathrm{N}^{2}$ waters significantly reduced over summer, suggesting that mixing was important. Whether the pathways followed by part of the modified AW, embedded in mesoscale features, in 2013 (towards the basin interior over the slope) and 2018 (in Sofia Deep towards the tip of Yermak Plateau) constitute persistent advection routes is being evaluated in another work.

The recurrent outflows from the troughs, continuing throughout summer, led to horizontally narrow strips of thick low- $\mathrm{N}^{2}$ layers, observed along the slope at the end of summer in both years (Figures 17b and 17d). Observations have suggested outflows from troughs in the northwest Barents Sea (e.g. Matishov et al., 2009; Pfirman et al., 1994; Schauer et al., 1997). These remain poorly documented yet. As noted in Schauer et al. (1997) the dense winter-conditioned waters that drain from the shelf into the Nansen Basin as discrete local buoyancy-driven plumes from the troughs have regionally different temperature-salinity properties. These characteristics most likely vary seasonally and inter-annually (Lind \& Ingvaldsen, 2012). Further work is needed to examine model performance in the Barents Sea and distinguish and quantify contributions from the different troughs.

Winter 2012/13 was exceptional with respect to winter mixed layer depths in the Western Nansen Basin and the northern Barents Sea and was only outclassed by winter 2017/18 over the northern Yermak Plateau and Sofia Deep (Figure 8e).

The 14 years of model fields highlighted the considerable interannual variations over the Marginal Convection Zones of the Yermak Plateau and continental slope, with diverse ice-atmosphere conditions and winter MLDs varying from tens (e.g. 2010/11, 2014/15 and 2019/20) to hundreds of meters (e.g. 2012/ 13 and 2017/18; Figure 9). Model fields tended to indicate that the absence of ice cover was a necessary condition for the onset of deep winter convection. They also suggested that imported ice and meltwater, pushed by favorable winds, resulted in a stronger surface stratification causing deep convection to end (Figure 10). However, these hypotheses need further examination and quantification, in particular considering the large wind and sea-ice variability in the area (Supporting Information S1 and S2).

The time series showed that conditions previously encountered in 2007-2011 in both areas with no openocean, 50 m-ocean temperatures below $0{ }^{\circ} \mathrm{C}$ and MLDs shallower than $100 \mathrm{~m}$ changed significantly around mid-2011. From then on, the ocean was occasionally ice-free, 50-m-ocean temperatures always above $0{ }^{\circ} \mathrm{C}$ and MLD and ocean-to-atmosphere heat fluxes exhibited large interannual variations (including the extreme winters reported in this study; Figure 9). In the northern YP and continental slope areas, the increased occurrences of these conditions previously only observed in the "Whalers' Bay" (a quasi-permanent polynya northwest of Svalbard; Onarheim et al., 2014) confirmed the evolution inferred by Polyakov et al. (2017) in the eastern Eurasian Basin over 2003-2015, with sea-ice decline and shoaling of the AW layer allowing deeper winter ventilation. The causes for these changes remain unclear, as a wide variety of feedbacks and pre-conditioning processes come into play (Cullather et al., 2016; Ivanov et al., 2016; Skagseth et al., 2020) and drive the upper-ocean conditions both locally and upstream.

Winter convection is a key process in the formation of the lower halocline waters of the Arctic Ocean (e.g. Pfirman et al., 1994; Rudels et al., 2004; Steele et al., 1995). Recently, using the NO geochemical tracer, Bertosio et al. (2020) showed that the base of the lower halocline which used to be associated with $\mathrm{SA} \sim 34.46 \mathrm{~g} / \mathrm{kg}$ (34.3 psu) was now found on a saltier level of $34.9 \mathrm{~g} / \mathrm{kg}$ in the Eurasian Basin. This denser level, corresponding to isopycnal $27.85 \mathrm{~kg} / \mathrm{m}^{3}$, is in agreement with the deeper winter mixed layers reproduced by PSY4 in Nansen Basin: during the extreme winters 2012/13 and 2018/17, deep convection reached the $27.95 \mathrm{~kg} / \mathrm{m}^{3}$ isopycnal. Exploratory 2-D Lagrangian trajectories using PSY4 velocities suggested advective pathways from the continental slope to the center of the Nansen Basin in the 30-150 m layer (i.e. halocline waters), with time scales larger than 3 years (Bertosio et al., 2020). Full 3-D Lagrangian 
tracking would extend this precursory work and improve our understanding of the fate of the convected water and its impact on the halocline water properties.

In this region where observations require considerable efforts and resources, the PSY4 physical system proved to be a good tool to assess AW modification through winter convection. PSY4 showed the additionally important role of shelf-to-basin exchange across the Arctic troughs of the Western Nansen Basin. Mixed layer depths exhibited large interannual variations, explaining the diverse in-situ observations. As the transition towards a seasonally ice-free Arctic Ocean continues, more years of extreme deep mixed layers and enhanced convection can be expected.

\section{Appendix A: Evaluation of PSY4 bathymetry in the Western Nansen Basin}

The International Bathymetric Chart of the Arctic Ocean (IBCAO) is a regional, Arctic Ocean-dedicated bathymetry (Figure A1a). The latest version 3.0 used in this study has a $500 \mathrm{~m}$ grid spacing and gathers a significant number of new bathymetric data from diverse sources (Jakobsson et al., 2012).

In contrast, the bathymetry used in the PSY4 is a combination of the ETOPO1 bathymetry (Earth Topography and bathymetry; Amante \& Eakins, 2009) for deeper oceans and the GEBCO8 bathymetry (General Bathymetric Chart of the Oceans; Becker et al., 2009) on the coast and continental shelf (as described in section 2.1). ETOPO1 is a 1 arc-minute global relief model integrating both land topography and ocean bathymetry. GEBCO8 is a global bathymetry product with 30 arc-second grid resolution. The resulting composite bathymetry is interpolated on the PSY4 native grid (Figure A1b).

We interpolated IBCAO to the PSY4 grid to allow the evaluation of the model bathymetry in the Western Nansen Basin. Comparisons between the PSY4 and IBCAO bathymetries highlighted significant discrepancies on the continental slope north-east of Svalbard. Indeed, the mouth of Kvitøya Trough (KT) was too wide in PSY4, with a western flank reaching as far as $25^{\circ} \mathrm{E}$ instead of $28^{\circ} \mathrm{E}$ in IBCAO. As a consequence, the shelf west of KT was up to $400 \mathrm{~m}$ too deep (blue signal in Figure A1c). Additionally, the abrupt northward bifurcation of isobaths 2000 to $3,000 \mathrm{~m}$, found at $32-34^{\circ} \mathrm{E}$ in IBCAO, was smoother and began further west in the PSY4 bathymetry (from $30^{\circ} \mathrm{E}$ ). The PSY4 slope (500 to $1,000 \mathrm{~m}$ isobaths) was also about $15-20 \mathrm{~km}$ more

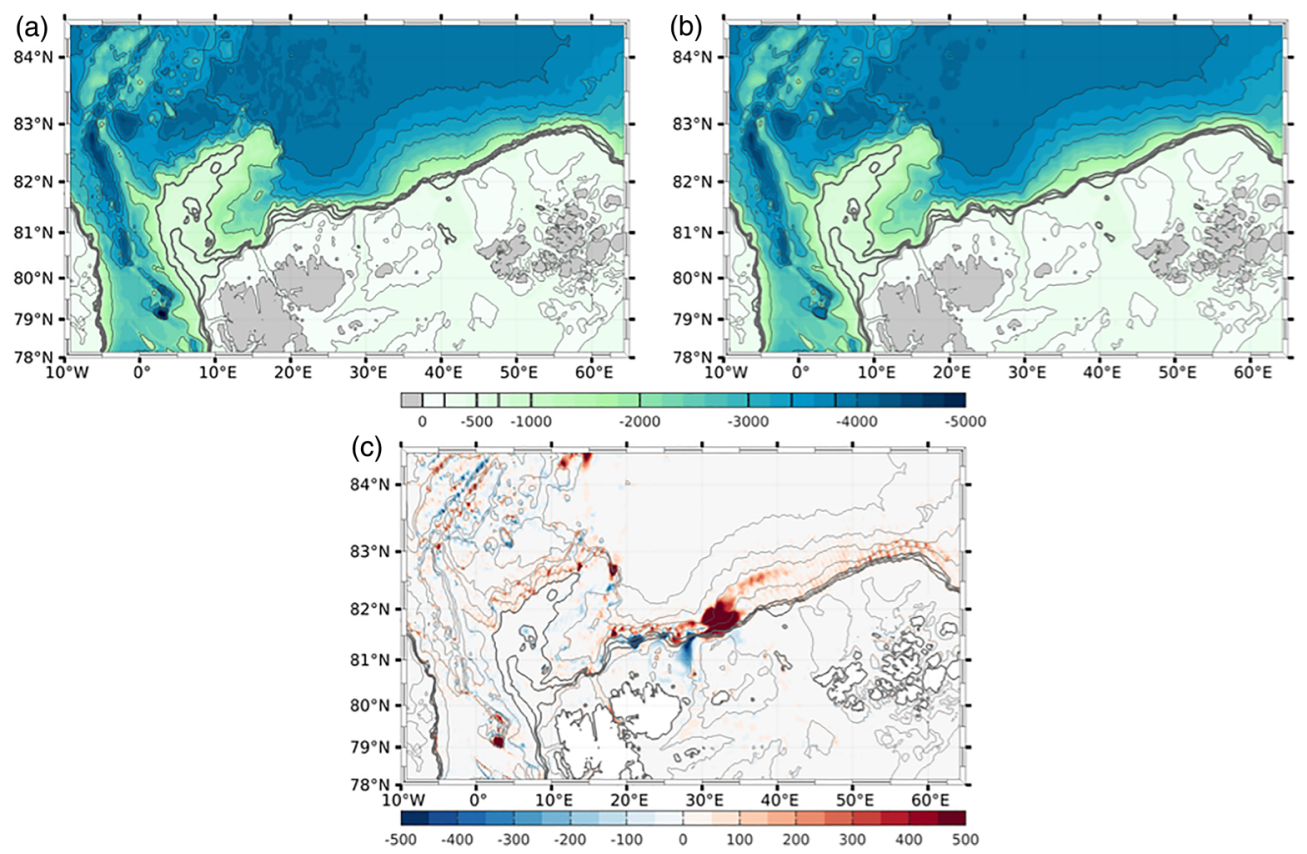

Figure A1. Comparison of (a) IBCAO bathymetry and (b) PSY4 bathymetry. Isobaths 0, 200, 500, 1,000, 2000, 3,000, $3,400,3,800 \mathrm{~m}$ are plotted and indicated in the color bar. (c) Differences between the two bathymetries (ETOPOIBCAO) blue implies that the model bathymetry (ETOPO) is too deep, red that it is too shallow. Isobaths plotted in background are from IBCAO for sake of reference. 
north at $30-35^{\circ} \mathrm{E}$. Hence, the model bathymetry stood out with shallower bathymetry in this area (red signal in Figure A1c). Elsewhere in the basin, the comparison was very satisfactory, with local differences larger than $50 \mathrm{~m}$ only in sharp slope areas, and never exceeding $50 \mathrm{~m}$ otherwise.

\section{Acknowledgments}

We are grateful to all the people that contributed to gather the observations used for model validation in this study. The data sources and corresponding web sites are compiled in Table 1 . The model outputs are available at Copernicus Marine Environment Monitoring Service (CMEMS; http:// marine.copernicus.eu/). Discussions with Léa Poli are greatly acknowledged. Marylou Athanase was supported through the Pan-Arctic Options Belmont Forum project (ANR-14AORS-003-01). Cecilia Bertosio was supported through IAOOS grant A18JROI002 at Sorbonne University. M. Dolores Pérez-Hernández is supported through the "Programa Postdoctoral de la Universidad de Las Palmas de Gran Canaria”. We are deeply grateful to editor Laurence Padman and three anonymous reviewers for their thorough comments which helped us improve the manuscript.

\section{References}

Aagaard, K., Foldvik, A., \& Hillman, S. R. (1987). The West Spitsbergen current: Disposition and water mass transformation. Journal of Geophysical Research, 92(C4), 3778-3784. https://doi.org/10.1029/JC092iC04p03778

Alkire, M. B., Polyakov, I., Rember, R., Ashik, I. M., Ivanov, V., \& Pnyushkov, A. V. (2017). Lower halocline water formation and modification, a comparison of physical and geochemical methods. Ocean Science, 13(6), 983-995. https://doi.org/10.5194/os-13-983-2017

Amante, C. \& Eakins, B. W. (2009): ETOPO1 1 arc-minute global relief model: Procedures, data sources and analysis, NOAA Technical Memorandum NESDIS NGDC-24, 25 pp.

Appen, W. J. V., Schauer, U., Hattermann, T., \& Beszczynska-Möller, A. (2016). Seasonal cycle of mesoscale instability of the West Spitsbergen current. Journal of Physical Oceanography, 46(4), 1231-1254. https://doi.org/10.1175/JPO-D-15-0184.1

Athanase, M., Sennéchael, N., Garric, G., Koenig, Z., Boles, E., \& Provost, C. (2019). New hydrographic measurements of the upper Arctic Western Eurasian Basin in 2017 reveal fresher mixed layer and shallower warm layer than 2005-2012 climatology. Journal of Geophysical Research: Oceans, 124, 1091-1114. https://doi.org/10.1029/2018JC014701

Becker, J. J., Sandwell, D. T., Smith, W. H. F., Braud, J., Binder, B., \& Depner, J. (2009). Global bathymetry and elevation data at 30 arc seconds resolution: SRTM30PLUS. Marine Geodesy, 32(4), 355-371. https://doi.org/10.1080/01490410903297766

Behrendt, A., Sumata, H., Rabe, B., \& Schauer, U. (2018). UDASH - unified data base for arctic and subarctic hydrography. Earth System Science Data, 10(2), 1119-1138. https://doi.org/10.5194/essd-10-1119-2018

Bertosio, C., Provost, C., Sennéchael, N., Artana, C., Athanase, M., Boles, E., et al. (2020). The Western Eurasian Basin Halocline in 2017: Insights From Autonomous NO Measurements and the Mercator Physical System. Journal of Geophysical Research: Oceans, 125. https:// doi.org/10.1029/2020jc016204

Beszczynska-Möller, A., Fahrbach, E., Schauer, U., \& Hansen, E. (2012). Variability in Atlantic water temperature and transport at the entrance to the Arctic Ocean, 1997-2010. ICES Journal of Marine Science, 69(5), 852-863. https://doi.org/10.1093/icesjms/fss056

Boyd, T. J., \& D'Asaro, E. A. (1994). Cooling of the West Spitsbergen current: Wintertime observations west of Svalbard. Journal of Geophysical Research, 99(C11), 22,597-22,618. https://doi.org/10.1029/94JC01824

Boyer Montégut, C., Madec, G., Fischer, A., Lazar, A., \& Iudicone, D. (2004). Mixed layer depth over the global ocean: An examination of profile data and a profile-based climatology. Journal of Geophysical Research, 109, C12003. https://doi.org/10.1029/2004JC002378

Cokelet, E. D., Tervalon, N., \& Bellingham, J. G. (2008). Hydrography of the West Spitsbergen current, Svalbard branch: Autumn 2001. Journal of Geophysical Research, 113, C01006. https://doi.org/10.1029/2007JC004150

Crews, L., Sundfjord, A., Albretsen, J., \& Hattermann, T. (2018). Mesoscale eddy activity and transport in the Atlantic water inflow region north of Svalbard. Journal of Geophysical Research: Oceans, 123, 201-215. https://doi.org/10.1002/2017JC013198

Crews, L., Sundfjord, A., \& Hattermann, T. (2019). How the Yermak pass branch regulates Atlantic water inflow to the Arctic Ocean. Journal of Geophysical Research: Oceans, 124, 267-280. https://doi.org/10.1029/2018JC014476

Cullather, R. I., Lim, Y. K., Boisvert, L. N., Brucker, L., Lee, J. N., \& Nowicki, S. M. (2016). Analysis of the warmest Arctic winter, 2015-2016. Geophysical Research Letters, 43, 10,808-10,816. https://doi.org/10.1002/2016GL071228

Good, S. A., Martin, M. J., \& Rayner, N. A. (2013). EN4: Quality controlled ocean temperature and salinity profiles and monthly objective analyses with uncertainty estimates. Journal of Geophysical Research: Oceans, 118, 6704-6716. https://doi.org/10.1002/2013JC009067

Goszczko, I., Ingvaldsen, R. B., \& Onarheim, I. H. (2018). Wind-driven cross-shelf exchange-West Spitsbergen current as a source of heat and salt for the adjacent shelf in Arctic winters. Journal of Geophysical Research: Oceans, 123, 2668-2696. https://doi.org/10.1002/ 2017JC013553

Hattermann, T., Isachsen, P. E., von Appen, W. J., Albretsen, J., \& Sundfjord, A. (2016). Eddy-driven recirculation of Atlantic water in Fram Strait. Geophysical Research Letters, 43, 3406-3414. https://doi.org/10.1002/2016GL068323

Hu, X., Myers, P. G., \& Lu, Y. (2019). Pacific water pathway in the Arctic Ocean and Beaufort gyre in two simulations with different horizontal resolutions. Journal of Geophysical Research: Oceans, 124, 6414-6432. https://doi.org/10.1029/2019JC015111

Ivanov, V., Alexeev, V., Koldunov, N. V., Repina, I., Sandø, A. B., Smedsrud, L. H., \& Smirnov, A. (2016). Arctic Ocean heat impact on regional ice decay: A suggested positive feedback. Journal of Physical Oceanography, 46(5), 1437-1456. https://doi.org/10.1175/JPO-D15-0144.1

Ivanov, V., Smirnov, A., Alexeev, V., Koldunov, N. V., Repina, I., \& Semenov, V. (2018). Contribution of convection-induced heat flux to winter ice decay in the Western Nansen Basin. Journal of Geophysical Research: Oceans, 123, 6581-6597. https://doi.org/10.1029/ 2018JC013995

Jakobsson, M., Mayer, L., Coakley, B., Dowdeswell, J. A., Forbes, S., Fridman, B., et al. (2012). The international bathymetric chart of the Arctic Ocean (IBCAO) version 3.0. Geophysical Research Letters, 39, L12609. https://doi.org/10.1029/2012GL052219

Koenig, Z., Meyer, A., Provost, C., Sennéchael, N., Sundfjord, A., Beguery, L., et al. (2018). Cooling and freshening of the West Spitsbergen current by shelf-origin cold Core lenses. Journal of Geophysical Research: Oceans, 123, 8299-8312. https://doi.org/10.1029/2018JC014463

Koenig, Z., Provost, C., Sennéchael, N., Garric, G., \& Gascard, J.-C. (2017). The Yermak pass branch: A major pathway for the Atlantic water north of Svalbard? Journal of Geophysical Research: Oceans, 122, 9332-9349. https://doi.org/10.1002/2017JC013271

Koenig, Z., Provost, C., Villacieros-Robineau, N., Sennéchael, N., Meyer, A., Lellouche, J.-M., \& Garric, G. (2017). Atlantic waters inflow north of Svalbard: Insights from IAOOS observations and Mercator Ocean global operational system during N-ICE2015. Journal of Geophysical Research: Oceans, 122, 1254-1273. https://doi.org/10.1002/2016JC012424

Lellouche, J. M., Greiner, E., le Galloudec, O., Garric, G., Regnier, C., Drevillon, M., et al. (2018). Recent updates to the Copernicus marine service global ocean monitoring and forecasting real-time $1 / 12^{\circ}$ high-resolution system. Ocean Science, 14(5), 1093-1126. https://doi. org/10.5194/os-14-1093-2018

Lind, S., \& Ingvaldsen, R. B. (2012). Variability and impacts of Atlantic water entering the Barents Sea from the north. Deep Sea Research Part I: Oceanographic Research Papers, 62, 70-88. https://doi.org/10.1016/j.dsr.2011.12.007

Matishov, G. G., Matishov, D. G., \& Moiseev, D. V. (2009). Inflow of Atlantic-origin waters to the Barents Sea along glacial troughs. Oceanologica, 51(3), 321-340. https://doi.org/10.5697/oc.51-3.321 
Meyer, A., Sundfjord, A., Fer, I., Provost, C., Villacieros Robineau, N., Koenig, Z., et al. (2017). Winter to summer oceanographic observations in the Arctic Ocean north of Svalbard. Journal of Geophysical Research: Oceans, 122, 6218-6237. https://doi.org/10.1002/ 2016JC012391

Nilsen, F., Skogseth, R., Vaardal-Lunde, J., \& Inall, M. (2016). A simple shelf circulation model: Intrusion of Atlantic water on the West Spitsbergen shelf. Journal of Physical Oceanography, 46(4), 1209-1230. https://doi.org/10.1175/JPO-D-15-0058.1

Onarheim, I. H., Smedsrud, L. H., Ingvaldsen, R. B., \& Nilsen, F. (2014). Loss of sea ice during winter north of Svalbard. Tellus A: Dynamic Meteorology and Oceanography, 66(1), 23933. https://doi.org/10.3402/tellusa.v66.23933

Padman, L., Plueddemann, A., Muench, R., \& Pinkel, R. (1992). Diurnal Tides Near the Yermak Plateau. Journal of Geophysical Research, 97, 12,639-12,652. https://doi.org/10.1029/92JC01097

Peralta-Ferriz, C., \& Woodgate, R. A. (2015). Seasonal and interannual variability of pan-Arctic surface mixed layer properties from 1979 to 2012 from hydrographic data, and the dominance of stratification for multiyear mixed layer depth shoaling. Progress in Oceanography, 134, 19-53. https://doi.org/10.1016/j.pocean.2014.12.005

Pérez-Hernández, M. D., Pickart, R. S., Pavlov, V., Våge, K., Ingvaldsen, R., Sundfjord, A., et al. (2017). The Atlantic water boundary current north of Svalbard in late summer. Journal of Geophysical Research: Oceans, 124, 1699-1716. https://doi.org/10.1029/2018JC014299

Pérez-Hernández, M. D., Pickart, R. S., Torres, D. J., Bahr, F., Sundfjord, A., Ingvaldsen, R., et al. (2019). Structure, transport, and seasonality of the Atlantic water boundary current north of Svalbard: Results from a yearlong mooring Array. Journal of Geophysical Research: Oceans, 124, 1679-1698. https://doi.org/10.1029/2018JC014759

Pfirman, S. L., Bauch, D., \& Gammelsrød, T. (1994). The Northern Barents Sea: Water Mass Distribution and Modification. In O. M. Johannesen, et al. (Eds.), The Polar Oceans and Their Role in Shaping the Global Environment, Geophysical Monograph Series (Vol. 85, pp. 77-94). Washington, DC: AGU. https://doi.org/10.1029/GM085p0077

Polyakov, I. V., Pnyushkov, A. V., Alkire, M. B., Ashik, I. M., Baumann, T. M., Carmack, E. C., et al. (2017). Greater role for Atlantic inflows on sea-ice loss in the Eurasian Basin of the Arctic Ocean. Science, 356(6335), 285-291. https://doi.org/10.1126/science.aai8204

Renner, A. H. H., Sundfjord, A., Janout, M. A., Ingvaldsen, R., Beszczynska-Möller, A., Pickart, R., \& Pérez-Hernández, M. (2018). Variability and redistribution of heat in the Atlantic water boundary current north of Svalbard. Journal of Geophysical Research: Oceans, 123, 6373-6391. https://doi.org/10.1029/2018JC013814

Rudels, B., Jones, E. P., Schauer, U., \& Eriksson, P. (2004). Arctic sources of the Arctic Ocean surface and halocline waters. Polar Research, 23(2), 181-208. https://doi.org/10.1111/j.1751-8369.2004.tb00007.x

Rudels, B., Korhonen, M., Schauer, U., Pisarev, S., Rabe, B., \& Wisotzki, A. (2015). Circulation and transformation of Atlantic water in the Eurasian Basin and the contribution of the Fram Strait inflow branch to the Arctic Ocean heat budget. Progress in Oceanography, 132, 128-152. https://doi.org/10.1016/j.pocean.2014.04.003

Schauer, U., Fahrbach, E., Osterhus, S., \& Rohardt, G. (2004). Arctic warming through the Fram Strait: Oceanic heat transport from 3 years of measurements. Journal of Geophysical Research, 109, C06026. https://doi.org/10.1029/2003JC001823

Schauer, U., Muench, R. D., Rudels, B., \& Timokhov, L. (1997). Impact of eastern Arctic shelf waters on the Nansen Basin intermediate layers. Journal of Geophysical Research, 102(C2), 3371-3382. https://doi.org/10.1029/96JC03366

Skagseth, O., Eldevik, T., Arthun, M., Asbjornsen, H., Lien, V. S., \& Smedsrud, L. H. (2020). Reduced efficiency of the Barents Sea cooling machine. Nature Climate Change, 10(7), 661-666. https://doi.org/10.1038/s41558-020-0772-6

Steele, M., Morison, J., \& Curtin, T. B. (1995). Halocline water formation in the Barents Sea. Journal of Geophysical Research, 100(C1), 881-894. https://doi.org/10.1029/94JC02310

Våge, K., Pickart, R. S., Pavlov, V., Lin, P., Torres, D. J., Ingvaldsen, R., et al. (2016). The Atlantic water boundary current in the Nansen Basin: Transport and mechanisms of lateral exchange. Journal of Geophysical Research: Oceans, 121, 6946-6960. https://doi.org/10.1002/ 2016JC011715

Wekerle, C., Wang, Q., von Appen, W. J., Danilov, S., Schourup-Kristensen, V., \& Jung, T. (2017). Eddy-resolving simulation of the Atlantic water circulation in the Fram Strait with focus on the seasonal cycle. Journal of Geophysical Research: Oceans, 122, 8385-8405. https:// doi.org/10.1002/2017JC012974 